\title{
Working
}

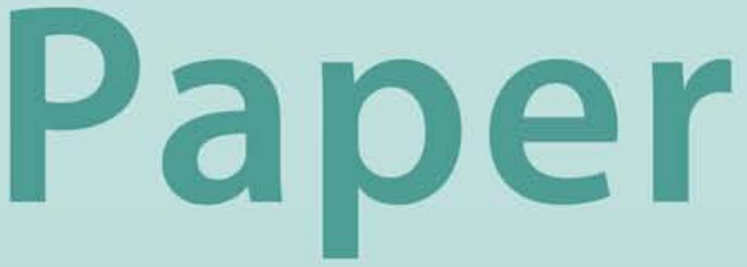




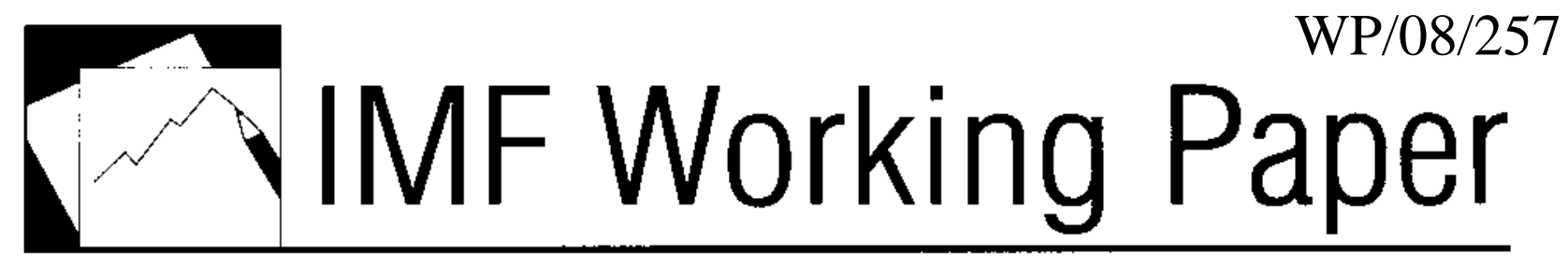

\title{
Tax Concessions and Foreign Direct Investment in the Eastern Caribbean Currency Union
}

\author{
Jingqing Chai and Rishi Goyal
}




\title{
IMF Working Paper
}

Western Hemisphere Department

\section{Tax Concessions and Foreign Direct Investment in the Eastern Caribbean Currency Union}

\author{
Prepared by Jingqing Chai and Rishi Goyal ${ }^{1}$
}

Authorized for distribution by Paul Cashin

November 2008

\begin{abstract}
This Working Paper should not be reported as representing the views of the IMF. The views expressed in this Working Paper are those of the author(s) and do not necessarily represent those of the IMF or IMF policy. Working Papers describe research in progress by the author(s) and are published to elicit comments and to further debate.

Tax concessions have been employed as a central component of the development strategy in the small island states comprising the Eastern Caribbean Currency Union. This paper compares the costs of concessions in terms of revenues forgone with the benefits in terms of increased foreign direct investment. The costs are very large, while the benefits appear to be marginal at best. Forgone tax revenues range between $9 \frac{1}{2}$ and 16 percent of GDP per year, whereas total foreign direct investment does not appear to depend on concessions. A rethinking of the use of concessions in the region is needed urgently.
\end{abstract}

JEL Classification Numbers: E62, F21, H25, O54

Keywords: Concessions, Incentives, Tax Competition, Foreign Direct Investment, ECCU

Authors’ E-Mail Addresses: jchai@imf.org, rgoyal@imf.org

\footnotetext{
${ }^{1}$ We are grateful to the country authorities in the Eastern Caribbean Currency Union and the staff of the Eastern Caribbean Central Bank for providing data and useful comments. We are also grateful to Ratna Sahay, David O. Robinson and Paul Cashin for their support and insights, and to Nigel Chalk, Michael Keen, Daehaeng Kim, Shawn Ladd, Timothy Lane, Montford Mlachila, Timothy Muzondo, Sebastian Sosa, Christopher Towe, Shang Jin Wei and seminar participants at the IMF for their helpful suggestions.
} 


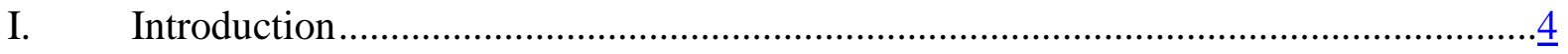

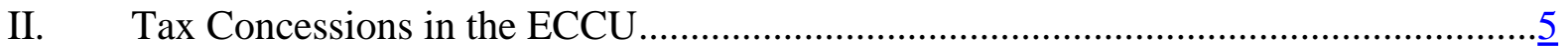

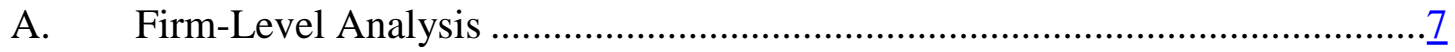

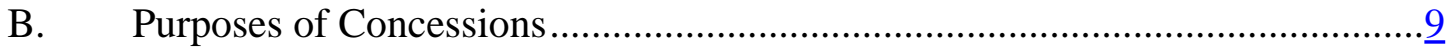

III. Revenue Costs of Concessions ..........................................................................

A. Exemptions from Import Duties and Taxes ............................................10

B. Corporate Income Tax Holidays .............................................................

C. Revenue Collection from Removing Concessions:

An Elasticies Approach...................................................................... 14

IV. Benefits of Incentives: FDI Performance in the ECCU ........................................15

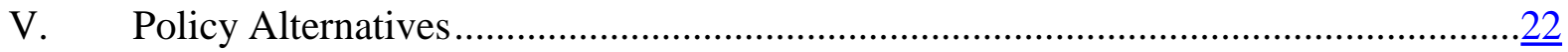

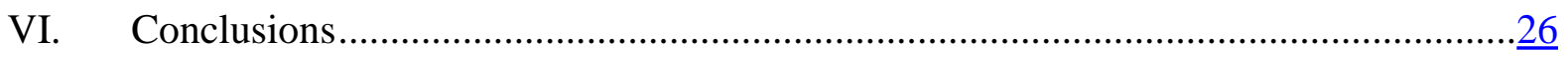

Appendices

I. Calculating the Change in Revenue from Removing Import-Related

Tax Concessions ...................................................................................... 27

II. Constructing Foreign Direct Investment Regime Indices.......................................28

Figures

1. Regional Comparisons: GDP Growth and Tourism Receipts...................................

2. ECCU: Import-Related Taxes and Revenue Forgone from Concessions ....................11

3. ECCU: Corporate Income Taxes and Revenue Forgone from Concessions ................13

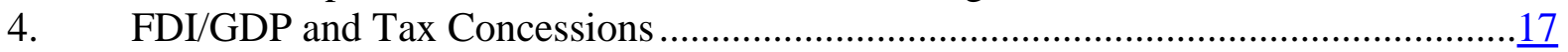

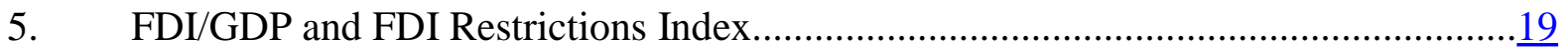

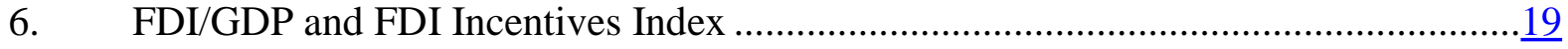

7. FDI/GDP and Statutory Corporate Income Tax Rate ........................................20

8. FDI/GDP and Statutory Import-Related Tax Rate.............................................. 20

Tables

1. Firm Size and Concessions: A Rank Correlation Analysis ...................................... $\underline{8}$

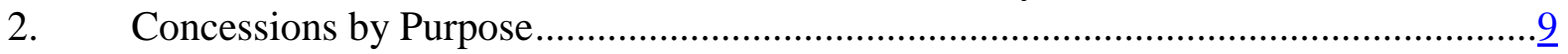

3. ECCU: Customs Revenue Losses from Concessions ............................................10

4. ECCU: Corporate Income Tax Collections ......................................................13

5. Revenue Gains from the Removal of Concessions: An Elasticities Approach ............15

6. FDI Performance Index........................................................................... 
7. Data for Cross-Country Regression Analysis: Summary Statistics................................18

8. Cross-Country Ordinary Least Square Regressions:

Dependent Variable Ln (FDI/GDP)......

9. Cross-Country Ordinary Least Square Regressions:

Dependent Variable Ln (FDI per capita) ……………………………………......22

10. Tax Holidays: An Illustrative Example ………………………………......................

11. Accelerated Depreciation and Loss Carry Forward: An Illustrative Example .............25

Appendix Tables

II.1. Government Policies Toward Foreign Direct Investment ............................................29

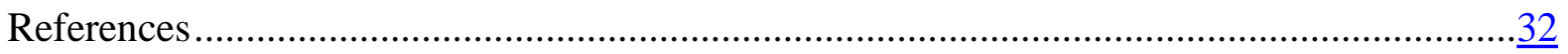




\section{INTRODUCTION}

Tax concessions-defined as preferential tax treatment for certain types of firms or entities-are commonplace in developed as well as developing countries. Concessions are granted to promote investment, in which case they may be termed "tax incentives" or "investment incentives,” or to achieve defined social objectives. For example, corporate income tax (CIT) holidays for five to ten years may be granted to firms that export goods and services or that locate in designated areas or regions. Exemptions from import-related duties and taxes may also be given, which may be on capital imports to promote investment, or on a wide range of other imported goods for statutory or civic bodies or nonprofit organizations.

Cross-country experience in the use of tax concessions is varied. The trend of using tax concessions to attract foreign direct investment (FDI) has continued, and some countries have granted increasingly generous concessions, for instance, by extending the duration of existing tax holidays. However, realizing that concessions can be very costly as a tool to promote investment, many countries have begun taking legal and administrative steps to restrict eligibility criteria and enforce compliance (UNCTAD, 1996; Easson, 2004).

Evidence on the effect of tax incentives in developing countries is limited. The emerging consensus from this research is that a country's overall economic characteristics may be more important for attracting successful investments than any tax incentive; and even if tax incentives play a role in securing an investment, they are not generally cost effective (Zee, Stotsky, and Ley, 2002). In a recent survey of 159 multinational firms operating in the Caribbean, tax concessions were not among the top 15 of the 40 areas that firms considered critical for their investments (Foreign Investment Advisory Service, 2004; World Bank, 2005). Although there is some evidence that when all else is equal, tax concessions can tilt the balance in favor of a particular location, it is generally considered much more effective for a country to attract investment by building genuine economic advantages and a conducive investment environment-including a stable, low, and transparent tax policy_rather than by simply offering incentives (UNCTAD, 2004). Based on individual country experience, Easson (2004) shows that competition often leads to overly generous terms, rendering the investments cost ineffective.

Another branch of the literature, with generally similar findings, has examined the effect of taxes on FDI. Because of sparse data, tax incentives have not been analyzed directly. Various measures of the tax rate have been used, such as the statutory rate on investment or the average effective or marginal effective tax rate on investment, where the effective rates attempt to capture the role of incentives (Zee, Stotsky, and Ley, 2002; Sosa, 2006). 
This paper adds to the literature on tax concessions in developing countries. It documents the use of concessions in six Eastern Caribbean Currency Union (ECCU) member countries, ${ }^{2}$ assesses the costs in terms of revenue forgone, and evaluates the effect of tax incentive regimes on FDI in a wide sample of countries. It uses measures of tax incentive regimes as constructed in Wei (2000), ${ }^{3}$ expanding Wei's sample of 40 mostly middle- and high-income economies to cover many developing and emerging market economies.

The main finding is that the ECCU countries rely heavily on the use of tax concessions, and that reliance on these concessions has increased significantly in Antigua and Barbuda and in St. Kitts and Nevis. In the region, tax revenues forgone are large, ranging from $91 / 2$ to 16 percent of GDP annually, while the effect of tax incentive regimes on FDI appears to be modest.

Previous work on tax concessions in the ECCU has analyzed costs in terms of revenues forgone and proposed administrative reforms. Bain (1995) assessed the costs in the early 1990s, while Andrews and Williams (1999) suggested that the regime of administering concessions be streamlined. Lecraw (2003) made the case for a coordinated, harmonized approach to granting concessions. This paper builds on this work, providing updated and additional calculations of revenue forgone, and analyzing benefits in terms of attracting FDI. ${ }^{4}$

Section II provides a brief overview of the practices in the ECCU for granting tax concessions. Section III estimates the revenue costs of the tax concessions, while Section IV examines the benefits in terms of attracting FDI. Section V offers policy recommendations, and the last section concludes.

\section{TAX CONCESSIONS IN THE ECCU}

Tax concessions have been employed as a central component of the development strategy of the ECCU member countries. The purposes for which concessions are granted can be broadly divided into two categories: tax concessions granted to induce investment (also called tax incentives), and concessions granted for regional, social and welfare purposes.

Concessions for investment in sectors such as tourism and light manufacturing have generally been provided through the member countries’ Fiscal Incentives Act, Aid to Pioneer

\footnotetext{
${ }^{2}$ This paper studies the six ECCU countries that are members of the IMF: Antigua and Barbuda, Dominica, Grenada, St. Kitts and Nevis, St. Lucia, and St. Vincent and the Grenadines.

${ }^{3}$ Wei (2000) examined the effect of corruption on FDI and found that FDI restrictions discourage such investment, while incentives encourage such investment.

${ }^{4}$ An earlier version of this work can also be found in Chai and Goyal (2006). See also Bauer, Cashin and Panth (2008) for additional work on tax incentives in the Caribbean.
} 
Industries Act, Hotels Aid Act, and sector-specific acts (such as the Offshore Banking Act and the International Business Companies Act). Tax concessions granted for regional, social and welfare purposes are provided in the Common External Tariff Act, in specific legislation covering statutory bodies, state enterprises, large individual institutions (such as utilities), or in special government arrangements with regional or international bodies regarding the tax treatment of diplomats and returning residents.

Concessions are typically granted in the form of import-related tax exemptions and Corporate Income Tax (CIT) holidays, and there is some evidence that competition in the tourism market has led to more generous terms of concessions as provided in the Hotels Aid Act. Exemptions from import-related taxes (import duties and the general consumption tax) on the importation of capital goods (raw materials and equipment) are the most common forms of concessions. Such exemptions may be on 100 percent of taxes and duties owed, or for lesser amounts. They may also be granted for varying lengths of time. Similarly, holidays on CIT may be of varying amounts and lengths of time. While little data are available on how the terms of the concessions have evolved over time, increasingly generous concessions appear to have been given. For instance, tax holidays granted to certain tourism facilities have been extended from a maximum of 5 to 25 years.

While individual country experience in the region varies, the process of granting tax concessions appears to involve considerable discretion and a lack of transparency and monitoring. The laws do not provide detailed procedural rules or specific criteria for granting concessions. Rather, the cabinet and/or minister of finance is vested with the authority to grant concessions, and in practice they have discretion in all aspects of a decision, including, for example, whether the legal requirements are fulfilled in an application and what the terms of the concessions should be for an application. ${ }^{5}$ Moreover, there is little public disclosure of information on the decision-making process and on awarded incentives, leaving many investors concerned over unequal treatment, market distortion, and favoritism. Finally, there is little monitoring of the beneficiaries of the incentives, and the conditions set out in the awarded incentives are often not enforced, potentially leading to abuses of the system. Based on the experience of many other developing countries, these issues together tend to provide scope for rent-seeking activities and negatively affect the investment environment.

The widespread use of tax concessions has been cited as justifiable because of increased competition in the tourism market in the wider Caribbean, and because of the reported threat by firms that they would leave if the concession was not granted. Indeed, the ECCU increasingly has faced tougher competition from other Caribbean countries (Figure 1). ${ }^{6}$ The

\footnotetext{
${ }^{5}$ Some countries have established agencies to promote investments, including through the granting of incentives.

${ }^{6}$ Hotel room capacity increased sharply in the wider Caribbean, while hurricane-related damage to hotel capacity in ECCU countries such as Antigua and Barbuda was significant.
} 
authorities consider that they are competing for similar investments and feel compelled to offer generous incentive packages out of fear that potential investors will locate their investments in neighboring countries, even as multinationals and other large regional firms play one island off another. They may also extend incentives on existing investments to keep investors from relocating. The argument is often made in terms of the employment impact; given the small size of the economies, the expected impact of some of the projects is sometimes a double-digit percentage of the labor force. As a consequence, the 1973 CARICOM Agreement to harmonize concessions has not been implemented (Lecraw, 2003).

Figure 1. Regional Comparisons: GDP Growth and Tourism Receipts, 1980-2003
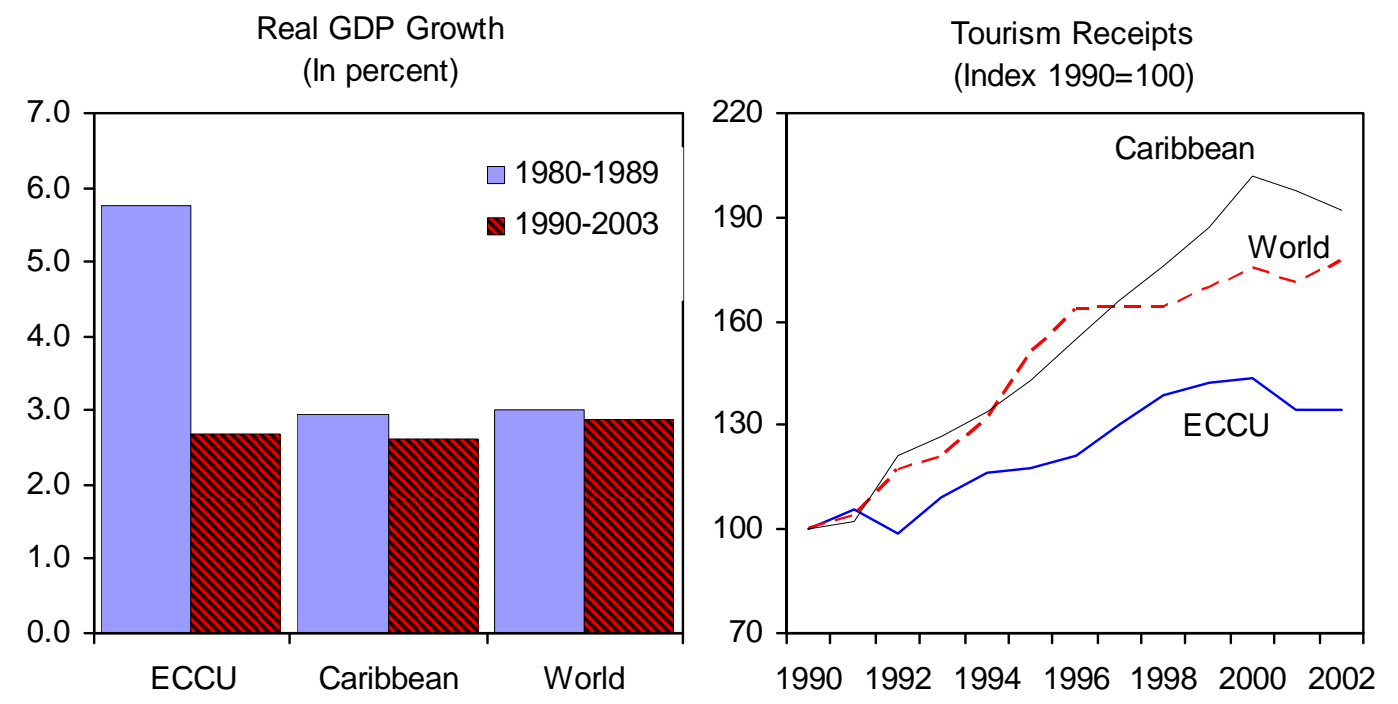

Source: Country authorities.

Given the widespread use of incentives, the perceived need for them is self perpetuating. Potential investments are at a cost disadvantage vis-à-vis existing investments in similar activities that receive incentives. Potential investors could argue for, and the authorities may feel compelled to offer, incentives to induce the new investment. One result is incentive dependence, that is, investments or firms remain continually dependent on the granting or renewal of incentives. The investment regime becomes anchored around the granting of incentives not only for new investments but also for existing ones. Such incentives become quasi-permanent subsidies for the operation of firms. A second result is that excessively generous incentives may be offered. As countries attempt to outbid one another for potential investments, the costs of incentives may outweigh the benefits. Such situations may result especially when there are political pressures to secure investments, and the costs are nontransparent or not well calculated.

\section{A. Firm-Level Analysis}

To examine the extent of concessions at the firm level, we collected a sample of 145 firms in the region receiving concessions from 1996 through 2000, covering such sectors as services, 
trade, and light manufacturing, but excluding tourism facilities owing to lack of data. All firms received exemptions from import-related taxes. About half also received exemptions from the CIT. The size of the firms varied substantially, from as few as two employees to as many as 450, and from capital investment of about US\$3,500 to US\$5 million. ${ }^{7}$

Exemptions from import-related taxes are widely granted and holidays from CIT are also used frequently. On average, a firm in the sample received a tax holiday of 2.6 years, a 32 percent reduction in the effective CIT rate, and a 91 percent reduction in the effective import duty and consumption tax rate. One of 10 firms received an export allowance, and one out of four received either a tax holiday extension or expanded coverage in import duties and consumption tax exemptions.

Concessions are granted to newly-established firms as well as to existing firms. Indeed, while tax incentives are often granted with the justification that future revenues may outweigh the present revenue forgone from granting these incentives, the sample provides evidence that concessions in the ECCU have been granted not only to newly-established enterprises but also to well-established firms. In 1996-97, about half of the firms receiving incentives had already been established, some several decades earlier. One of four existing firms had their concessions extended during 1996-97.

The size of firms matters. Large firms in terms of both employment and capital tended to receive longer tax holidays and face lower CIT rates (Table 1). Firms with higher employment also received export allowances, while more capital-intensive firms received extensions on existing holidays and exemptions and concessions on business expansions.

Table 1. Firm Size and Concessions: A Rank Correlation Analysis

\begin{tabular}{|c|c|c|c|c|c|}
\hline & $\begin{array}{c}\begin{array}{c}\text { Years of Tax } \\
\text { Holidays }\end{array} \\
\end{array}$ & $\begin{array}{c}\text { Reduction in } \\
\text { Effective CIT 1/ }\end{array}$ & $\begin{array}{l}\text { Reduction in } \\
\text { Effective Tariff 2/ }\end{array}$ & $\begin{array}{r}\text { Export } \\
\text { Allowance } \\
\end{array}$ & $\begin{array}{l}\text { Concession } \\
\text { Extension 3/ }\end{array}$ \\
\hline $\begin{array}{l}\text { Employment } \\
\text { (No. obs) }\end{array}$ & $\begin{array}{r}0.337^{*} \\
(161)\end{array}$ & $\begin{array}{r}0.320^{*} \\
(161)\end{array}$ & $\begin{array}{l}0.015 \\
(163)\end{array}$ & $\begin{array}{r}0.171^{*} \\
(163)\end{array}$ & $\begin{array}{l}0.123 \\
(165)\end{array}$ \\
\hline $\begin{array}{l}\text { Capital } \\
\text { (No. obs) }\end{array}$ & $\begin{array}{r}0.208^{\star} \\
(138)\end{array}$ & $\begin{array}{r}0.177^{*} \\
(138)\end{array}$ & $\begin{array}{r}-0.082 \\
(140)\end{array}$ & $\begin{array}{l}0.110 \\
(141)\end{array}$ & $\begin{array}{r}0.197^{*} \\
(141)\end{array}$ \\
\hline
\end{tabular}

Source: Authors' calculations.

$1 /$ Corporate income tax.

2/ Import duties and consumption taxes.

3/ Extensions of tax holidays and extensions and expansions in coverage of import duty and consumption tax exemptions.

Note: * denotes significance at 5 percent.

\footnotetext{
${ }^{7}$ Lack of ownership information on these firms precludes analysis of the question of whether foreign investors tend to receive more concessions than domestic investors. Also, lack of data on the cost of each concession granted or on the receiving firms' financial conditions precludes a cost-benefit analysis at the firm level.
} 


\section{B. Purposes of Concessions}

A detailed breakdown of concessions by purpose is not available except for Dominica and St. Vincent and the Grenadines for the early 2000s. In these two countries, data on customs revenue forgone from concessions are available by purpose (Table 2). Concessions granted under the Fiscal Incentives and Hotels Aid Acts, together with government agreements that deal with large special investors, accounted for less than 50 percent in value of the total customs duty concessions. Concessions granted by special cabinet decisions-mostly consumption-related decisions such as exemptions on personal vehicles-accounted for about 20 percent, whereas concessions related to government and statutory bodies (including public investment) were in the range of 9 to 14 percent of total concessions. It appears, therefore, that less than half the concessions were for investment purposes and the rest were for social and welfare purposes.

Table 2. Concessions by Purpose, 2001-2003 1/

(In percent of total)

\begin{tabular}{lrr}
\hline & Dominica & $\begin{array}{r}\text { St. Vincent and } \\
\text { the Grenadines }\end{array}$ \\
\hline Fiscal incentives 2/ & 30.2 & 9.5 \\
Special cabinet decisions & 21.0 & 23.3 \\
Government agreements 3/ & 15.8 & 33.1 \\
Government and statutory bodies & 9.2 & 13.7 \\
Personal effects and vehicles & 7.0 & 1.5 \\
Tourism & 3.9 & 0.3 \\
Civil servants and Parliamentarians 4/ & 3.5 & 0.3 \\
Primary industry & 2.5 & 0.7 \\
Military and diplomat & 2.5 & 0.8 \\
Other approved purposes & 2.0 & 1.2 \\
Charities and Churches & 1.4 & 0.3 \\
Education, culture, and health & 0.9 & 0.8 \\
Transportation & 0.0 & 0.6 \\
Unclassified & 0.0 & $\ldots$ \\
\hline
\end{tabular}

Sources: Country authorities and authors' calculations.

1/ Customs revenue forgone. Classification is based on SRO 18 codes of 2001.

2/ Primarily concessions granted under the Fiscal Incentive Act and the Hotel Aid Act.

3/ Special legislation involving, for insatnce, Cable \& Wireless, regional bodies, and large resorts.

4/ For Dominica, the code shows "Consumption Tax Order", which includes, among other things, concessions granted to civil servants to import cars free of duty.

\section{ReVEnUe Costs of ConCEssions}

The granting of tax concessions entails several costs: efficiency losses due to the preferential tax treatment to certain investors and consumers (except to correct market failures); revenue costs arising from forgone revenue; administrative costs; and social costs from corruption or 
rent seeking associated with the abuse of tax concession provisions (Zee, Stotsky, and Ley, 2002).

While all these costs could be substantial, little data are available to quantify them. The customs departments in the six ECCU countries compile some data on the revenue costs of concessions related to imports, as they verify the concessions vis-à-vis cabinet decisions and record the revenue forgone based on the reported import value. These data allow for estimating the revenue forgone from tax exemptions from import duties and consumption taxes for 2001-03 for each of the six ECCU countries.

The main finding is that overall revenue losses from concessions on import-related taxes and the CIT have been large in the ECCU countries, ranging between $91 \frac{1}{2}$ and 16 percent of GDP a year. As a percent of current revenues, the losses range between 30 and 70 percent. By comparison, although data on revenue forgone in other countries are generally not known, a recent study on the Philippines estimated revenue forgone at 1 to 2 percent of GDP annually (Easson, 2004).

\section{A. Exemptions from Import Duties and Taxes}

Revenue forgone from concessions on import duties or taxes have exceeded 8 percent of GDP annually and have increased over the past decade. Data collected by customs and excise departments in each country show that, in the early 2000s, exemptions granted ranged from 4.3 percent of GDP in Dominica to 12.2 percent in St. Kitts and Nevis (Table 3). In the early 1990s, exemptions granted were about 61/2 percent of GDP in the region, $1 \frac{1}{2} 2$ percent less than in the early 2000s. ${ }^{8}$

Table 3. ECCU: Customs' Revenue Losses From Concessions, 1991-2003 (In percent of GDP)

\begin{tabular}{lrr}
\hline & 1991-93 & 2001-03 \\
\hline Antigua and Barbuda & 5.1 & 9.2 \\
Dominica & 4.2 & 4.3 \\
Grenada & 11.4 & 11.3 \\
St. Kitts and Nevis & 5.8 & 12.2 \\
St. Lucia & 5.9 & 5.9 \\
St. Vincent and the Grenadines & 6.7 & 6.1 \\
ECCU average & 6.5 & 8.2 \\
\hline
\end{tabular}

Sources: Country authorities (Customs and Excise Departments); and Bain (1995).

\footnotetext{
${ }^{8}$ Data for the early 1990s are provided in Bain (1995).
} 
For a check of consistency, the customs and excise departments' estimates are compared to estimates derived from the difference between the statutory tax rate on imports (excise and duties) and the effective tax rate on imports. This difference may be exploited to estimate revenue losses. ${ }^{9}$ The statutory tax rate on imports is the sum of average import duties and consumption tax levied on imports. The effective tax rate is the ratio of revenues from international transactions to total imports.

The difference in tax rates ranges from more than 8 percent in Dominica to more than 22 percent in Antigua and Barbuda. This difference in rates yields revenue losses similar to those shown by data from the customs and excise departments of each country (Figure 2). Average losses are nearly 8 percent of GDP for the region, with ranges from about 4 percent of GDP in Dominica to over 12 percent in St. Kitts and Nevis.

Figure 2. ECCU: Import-Related Taxes and Revenue Forgone from Concessions, 2003
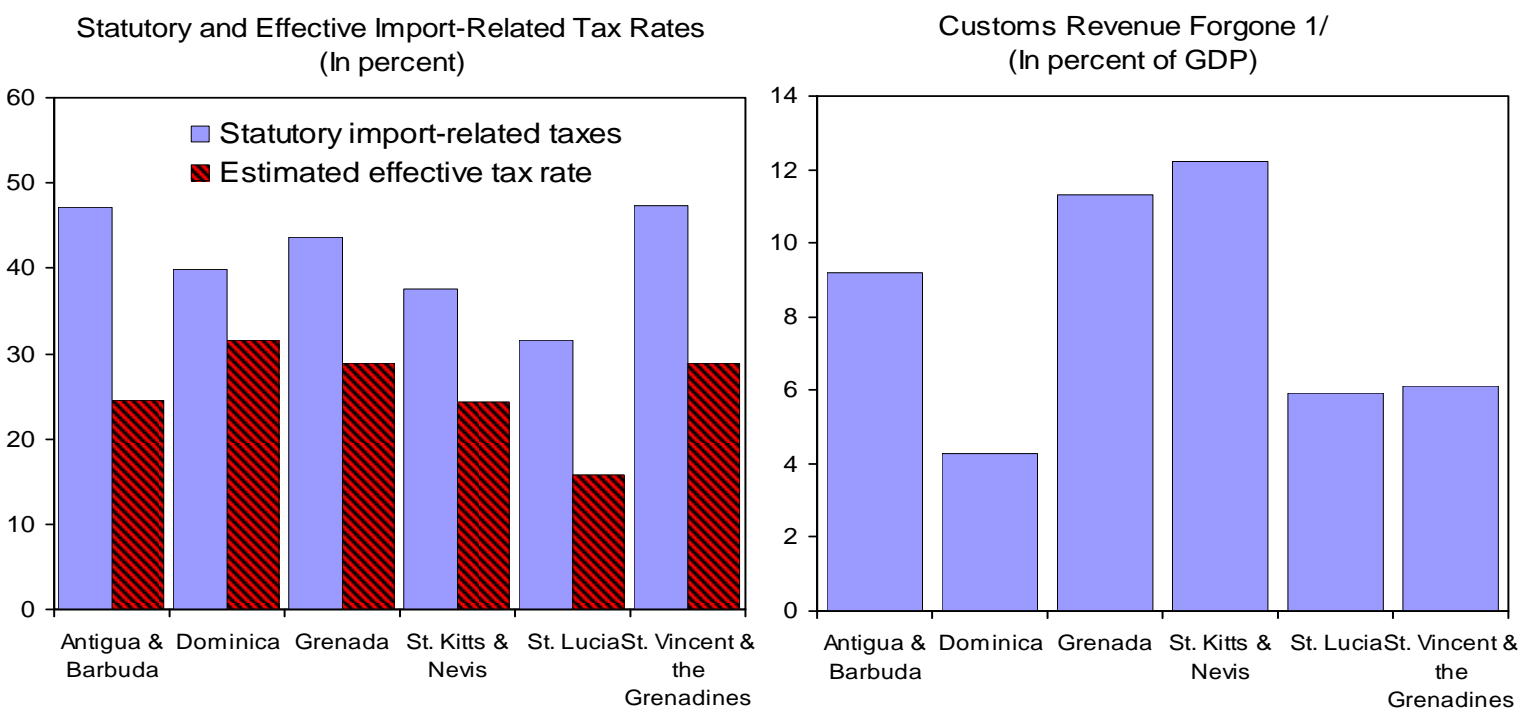

Sources: Country authorities (Customs and Excise Departments); and authors' calculations.

1/ Average for 2001-2003, from country authorities.

The increase in concessions since the early 1990s has been particularly evident in Antigua and Barbuda and in St. Kitts and Nevis. Customs revenue forgone in these two countries was about 5 percent of GDP a year higher in 2001-03 compared with the early 1990s.

Without data on the breakdown of the purposes for which the concessions were given, however, it is difficult to determine if the increased revenue costs of concessions in these two countries reflect the increasing use of tax concessions based on social and welfare

\footnotetext{
${ }^{9}$ Note that the revenue losses are due not only to concessions granted but also to leakages from administrative weaknesses.
} 
considerations or for attracting investments. For example, one possibility for the increased revenue forgone in Antigua and Barbuda and St. Kitts and Nevis is that concessions were increased to facilitate reconstruction after the severe natural disasters of the 1990s.

Furthermore, it is possible that changes in the revenue costs of concessions are due to inflation in imports or in profits rather than the use of concessions. Data on import prices are not available, but given the quasi-currency board arrangements and a stable dollar exchange rate, inflation in imports in the ECCU region has been broadly aligned with that in the U.S. goods market. Consumer price index inflation in the ECCU region-where most of the CPI basket is comprised of imports - has been low, at around 2 percent over the past decade. It can, therefore, be concluded that the increase in forgone revenue in Antigua and Barbuda and St. Kitts and Nevis reflects a higher incidence or more generous terms of tax concessions rather than inflation in imports and profits.

\section{B. Corporate Income Tax Holidays}

Revenue forgone from CIT holidays may have exceeded 4 percent of GDP annually. In the absence of data, forgone revenue is estimated from the difference between the statutory and the effective CIT rates. ${ }^{10}$ The effective CIT rates are calculated by dividing the CIT revenue by an estimated CIT base. ${ }^{11}$ Statutory rates have ranged between 30 and 40 percent in the region, whereas effective rates are between 6 and 20 percent. Given the large differences, estimated forgone revenue is also substantial, ranging from 3 percent of GDP in Grenada to about 6 percent of GDP in Antigua and Barbuda (Figure 3).

\footnotetext{
${ }^{10}$ Differences between the statutory and the effective CIT rates could inter alia reflect the complex nature of CIT systems, such as the treatment of investment, depreciation, interest payments, and debt-equity ratio of firms, as well as tax concessions.

${ }^{11}$ National accounts data on the income side are not available for the ECCU member countries. The corporate income tax base is assumed to be 25 percent of GDP, in line with the number for Jamaica.
} 
Figure 3. ECCU: Corporate Income Taxes and Revenue Forgone from Concessions, 2003
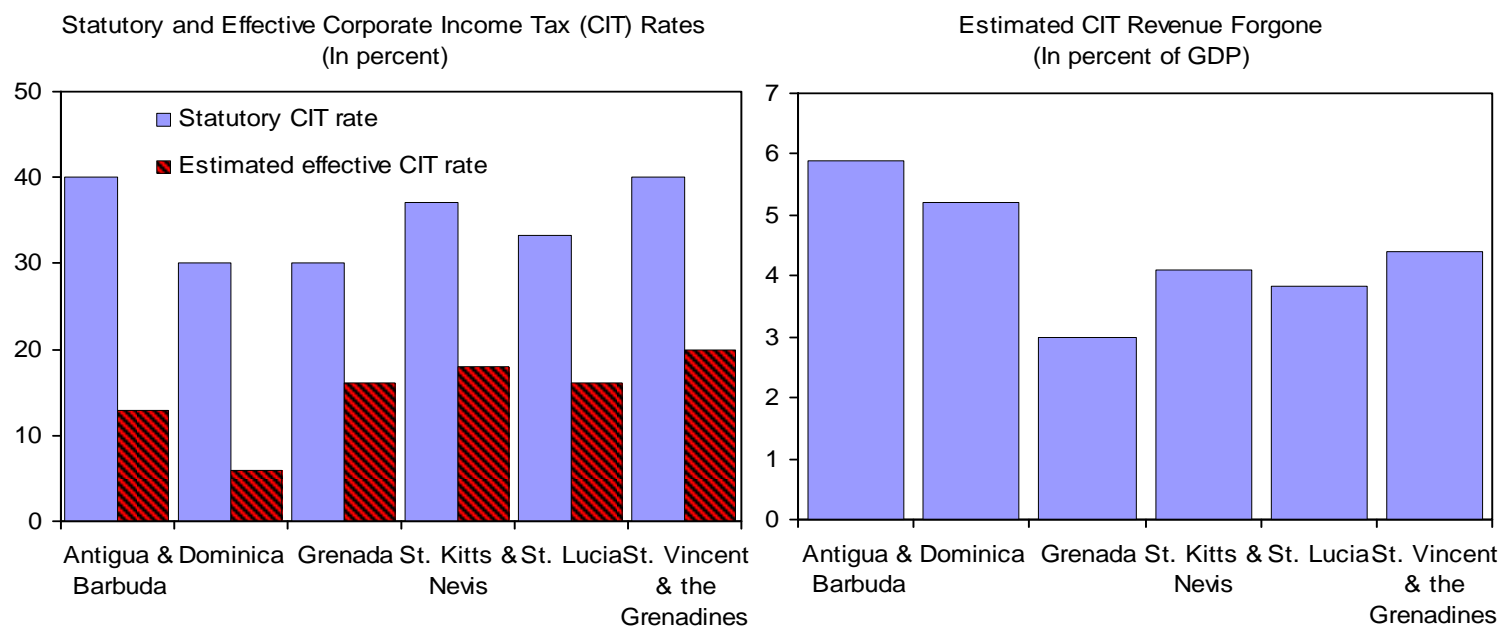

Sources: Country authorities; and authors' calculations.

CIT yields have declined since the early 1990s, which could reflect an expansion in concessions granted. The average yield fell moderately from 3.5 percent of GDP from 1990-94 to 3 percent from 1999-2003 (Table 4). Declines were observed in some countries, particularly Dominica, but increased somewhat in two countries, although from low bases.

Table 4. ECCU: Corporate Income Tax Collections, 1990-2003 (In percent of GDP)

\begin{tabular}{lrr}
\hline & 1990-94 & 1999-2003 \\
\hline Antigua and Barbuda & 2.1 & 2.5 \\
Dominica & 3.4 & 0.9 \\
Grenada & 3.2 & 3.6 \\
St. Kitts and Nevis & $\ldots$ & 2.7 \\
St. Lucia & 4.2 & 4.0 \\
St. Vincent and the Grenadines & 4.5 & 4.4 \\
ECCU average & 3.5 & 3.0 \\
\hline
\end{tabular}

Sources: Country authorities; and Fund staff estimates.

The decline in yields came at a time when CIT collections had eroded across many developing countries. With capital market integration appearing to have strengthened, low tax rates could be expected to apply to internationally-mobile capital, all else being equal. If low rates are not applied, capital could be moved to other lower tax rate destinations. Two assumptions were made to derive the estimates: perfect tax administration and an even distribution of the aggregate profits. ${ }^{12}$ Given a relatively-weak tax administration and a profit

\footnotetext{
${ }^{12}$ Distribution of profits and losses matters. For example, assume there are 20 companies and the sum of their profits is $\$ 100$. If the statutory tax rate is 30 percent, then statutory revenue would be $\$ 30$. However, if the
} 
distribution skewed toward larger firms with excess profits in the ECCU, the biases go in opposite directions. Because of the considerable problems with tax administration, part of the estimate is due to leakages in tax administration rather than increasing use of CIT concessions. This tends to bias our estimates of the tax concessions upward. Very little data are available to quantify the distribution of profits in the region. However, discussions with inland revenue departments and banks suggest that a handful of large firms that currently enjoy tax holidays and other tax concessions have been very profitable, while many smaller firms have been struggling, especially in low tourism seasons. Therefore, the "actual” CIT tax base may be greater if this uneven distribution of profits is taken into account. This means that the effective CIT rate may be overestimated, biasing downward the estimate of tax concessions.

\section{Revenue Collection from Removing Concessions: An Elasticities Approach}

A common perception is that investment and revenue collection would decline in the absence of concessions. While there is agreement that revenue is forgone due to concessions, some consider that investments would not have taken place without the concessions. Hence, they argue that the employment and revenue resulting from the new investments that benefit from concessions are net gains.

Calculations based on plausible price elasticities suggest that revenue collections could increase substantially by removing concessions. Depending on the elasticities, higher effective tax rates could offset declines in import volumes and corporate incomes were concessions to be removed. For instance, if import demand were perfectly inelastic, then import revenue collections would increase. But if import demand were elastic, then revenue collections would decrease (Appendix I).

Empirical studies have estimated relatively-inelastic import price elasticities for developing countries, ranging between -1.0 and -0.4 (Khan, 1974; Khan and Knight, 1988). Indeed, in small and highly-open economies such as those in the ECCU—which import the bulk of goods consumed and invested, and depend mainly on high-income, relatively price-inelastic tourist clienteles_-import demand is arguably inelastic.

Assuming a price elasticity of -0.7 both for import volumes and corporate incomes, the revenue gain from removing concessions is 9 percent of GDP on average, ranging from 8 percent of GDP for Dominica to 13 percent for St. Kitts and Nevis (Table 5).

distribution of profit is such that 15 companies make losses of $\$ 300$ and 5 make profits of $\$ 400$, then true statutory revenues are $\$ 120$. 
Table 5. Revenue Gains from the Removal of Concessions: An Elasticities Approach 1/ (In percent of GDP)

\begin{tabular}{lccc}
\hline & Import-related Taxes & Corporate Income Taxes & Total \\
\hline Antigua and Barbuda & 6.2 & 4.2 & 10.4 \\
Dominica & 3.1 & 4.1 & 7.2 \\
Grenada & 7.8 & 2.4 & 10.2 \\
St. Kitts and Nevis & 9.0 & 3.0 & 12.0 \\
St. Lucia & 4.6 & 2.9 & 7.6 \\
St. Vincent and the Grenadines & 4.1 & 3.2 & 7.3 \\
ECCU average & 5.8 & 3.3 & 9.1 \\
\hline
\end{tabular}

Source: Authors' calculations.

$1 /$ Assuming a price elasticity of -0.7 .

\section{Benefits of InCentives: FDI Performance in the ECCU}

The estimated revenue costs of tax concessions are large for the ECCU countries, begging the question of whether the costs are justified by benefits that may be derived from granting tax concessions. Possible benefits are delayed revenue benefits from induced investment and revenue from other type of taxes such as wage and hotel taxes. There are also perceived spillover benefits flowing from FDI such as job creation, technology transfer, and improved efficiency of domestic industries.

As shown above, possibly more than half of the tax concessions are used for various social and welfare purposes in the ECCU. The quantification of the benefits that may derive from achieving such objectives is beyond the scope of this paper. However, the conventional wisdom on social spending is that taxes and preferential tax treatments are not the best instruments by which to achieve social objectives. Moreover, granting concessions in a discretionary, opaque, or even arbitrary manner would provide scope for corruption and rent seeking, thereby negatively impacting the investment environment.

The second main policy motivation for tax concessions is to stimulate investment, both FDI and domestic investment, and to create employment. Despite the fact that concessions have increased over the past decade, the ECCU's world ranking of FDI as a share of GDP has fallen (Table 6), and greater concessions do not seem to be reflected in changes in the FDIto-GDP ratio (Figure 4). In an average ranking of the ratio of FDI to GDP of more than 150 countries, the ECCU countries fell from fifth to twentieth by $2002 .{ }^{13}$ The ECCU share of

\footnotetext{
${ }^{13}$ See World Bank (2005). Even though the relative ranking of the ECCU region has fallen over time, the share of FDI in GDP has remained high, reflecting the region's natural endowment as a prime tourist destination and the small size of its economies.
} 
Caribbean FDI inflows also declined from 12.3 to 3.7 percent over the same period (World Bank, 2005).

Table 6. FDI Performance Index 1/

\begin{tabular}{lrrrrr}
\hline & 1979-83 & 1984-88 & 1989-93 & 1994-98 & 1999-2003 \\
\hline Antigua and Barbuda & 24.1 & 12.3 & 11.4 & 3.5 & 2.6 \\
Dominica & 2.5 & 8.0 & 10.9 & 8.8 & 2.3 \\
Grenada & 1.8 & 7.1 & 8.5 & 6.2 & 5.3 \\
St. Kitts and Nevis & 12.3 & 16.4 & 19.2 & 7.0 & 8.4 \\
St. Lucia & 37.4 & 10.8 & 12.1 & 4.9 & 2.3 \\
St. Vincent and the Grenadines & 3.0 & 5.0 & 7.7 & 14.5 & 4.0 \\
ECCU & 16.0 & 11.7 & 11.7 & 8.1 & 4.3 \\
Small island economies 2/ & 7.0 & 8.9 & 7.6 & 6.7 & 8.2 \\
Latin America and the Caribbean & 1.8 & 1.5 & 1.4 & 2.0 & 1.6 \\
Developing countries & 1.4 & 1.2 & 1.4 & 1.8 & 1.2 \\
\hline
\end{tabular}

Sources: UNCTAD, World Investment Report 2004; and authors' calculations.

$1 /$ Performance index is the share of a country's FDI inflow in the world's FDI inflow, divided by the share of the country's GDP in the world's GDP.

2/ Includes the six ECCU member countries of the IMF, The Bahamas, Bermuda,

Cayman Islands,Cyprus, Dominican Republic, Guyana, Haiti, Jamaica, Malta, Mauritius,

Papua New Guinea, Samoa, Seychelles, and Trinidad and Tobago.

Measuring benefits in terms of employment is much more difficult, as no data are available on the employment generated by incremental investments or the other taxes derived from them. This data limitation precludes a cost-benefit analysis in terms of job creation or net revenue gain. However, as discussed earlier, the sample of firms receiving concessions in the region in the second half of the 1990s provides some evidence that the terms of the concessions are positively correlated with the size of the firms both in terms of capital and employment.

To more systematically analyze the effect of incentives on FDI, a broad cross-country study was conducted. Two indices were constructed —an FDI restrictions index and an FDI incentives index - using the methodology of Wei (2000). Wei's database was expanded to cover 80 countries (Appendix II). Besides FDI restrictions and incentives, other factors such as tax rates, institutional quality and infrastructural quality can impact FDI. So, data were 
Figure 4. FDI/GDP and Tax Concessions, 1991-2003

(Change in percentage points)

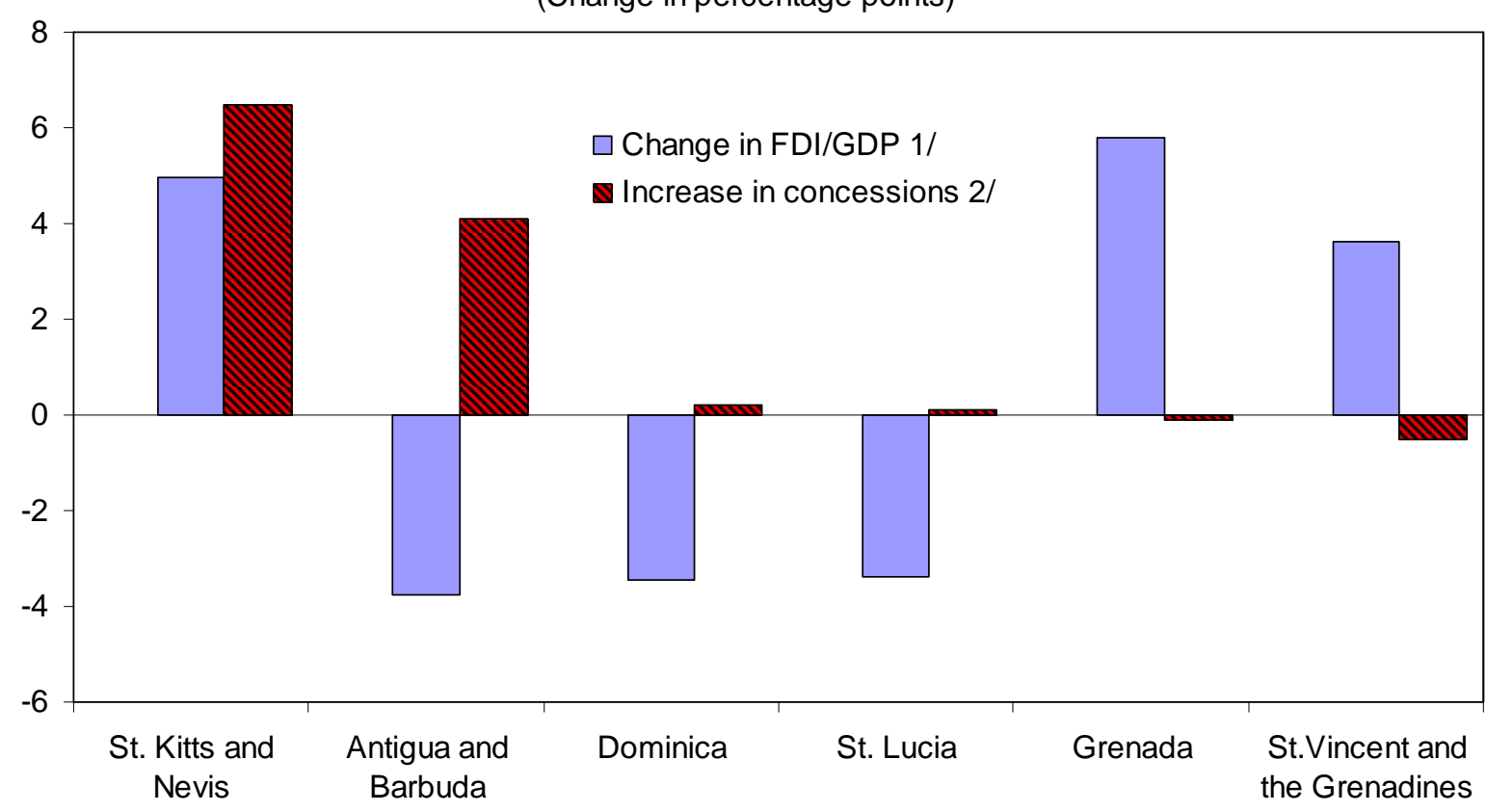

Sources: Country authorities; Eastern Caribbean Central Bank; and authors' calculations.

1/ Measured as the difference in FDI/GDP in 2001-03 relative to 1991-93.

2/ Measured as the difference in customs revenue forgone from concessions in 2001-03 relative to 1991-93.

collected on the tariff rate and the statutory corporate income tax rate, an institutional quality variable (governance), and an infrastructural quality variable (roads). Data for 2000 were used where available; otherwise, data for the most recent years were used.

Data on FDI are taken from UNCTAD’s World Investment Report (2004). The governance variable is from the World Bank Institute, and captures six dimensions of governance in a country — voice and accountability, political stability, government effectiveness, regulatory quality, rule of law, and control of corruption. The sum of the six variables is used. The road index is from the World Development Indicators (World Bank). The tariff variable is the average statutory tariff rate from the IMF's trade restrictiveness database, and includes import tariffs, other customs charges and fees. The corporate income tax rate is the statutory tax rate from the country authorities.

The summary statistics of the variables are shown in Table 7. The ECCU countries have a generally pro-FDI policy, with incentives provided for select sectors (notably offshore financial services, tourism, and manufacturing) and exports. The average CIT rate in the ECCU is 4 percentage points higher than in small island states, while the average import tariff rate is 2 percentage points higher. The quality of institutions and infrastructure in the ECCU is above average, but there remains considerable room for improvement as compared with the maximum achieved. 
Table 7. Data for Cross-Country Regression Analysis: Summary Statistics

\begin{tabular}{|c|c|c|c|c|c|}
\hline Variable & Mean & $\begin{array}{l}\text { Standard } \\
\text { Deviation }\end{array}$ & Minimum & Maximum & $\begin{array}{r}\text { No. of } \\
\text { Observations } \\
\end{array}$ \\
\hline \multicolumn{6}{|c|}{ FDI restrictions $1 /$} \\
\hline Overall sample & 1.3 & 1.2 & 0.0 & 4.0 & 80 \\
\hline ECCU & 0.0 & 0.0 & 0.0 & 0.0 & 6 \\
\hline Small island states & 0.4 & 0.7 & 0.0 & 2.0 & 20 \\
\hline \multicolumn{6}{|c|}{ FDI incentives 2/ } \\
\hline Overall sample & 1.9 & 0.8 & 0.0 & 3.0 & 80 \\
\hline ECCU & 2.0 & 0.0 & 2.0 & 2.0 & 6 \\
\hline Small island states & 2.3 & 0.6 & 1.0 & 3.0 & 19 \\
\hline \multicolumn{6}{|c|}{ Statutory corporate income tax rate } \\
\hline Overall sample & 32.0 & 9.0 & 0.0 & 60.0 & 123 \\
\hline ECCU & 35.0 & 4.0 & 30.0 & 40.0 & 6 \\
\hline Small island states & 31.1 & 11.6 & 0.0 & 45.0 & 22 \\
\hline \multicolumn{6}{|c|}{ Average import tariff } \\
\hline Overall sample & 11.8 & 6.9 & 0.0 & 37.2 & 140 \\
\hline ECCU & 16.2 & 2.1 & 14.1 & 19.6 & 6 \\
\hline Small island states & 14.3 & 6.7 & 6.5 & 34.0 & 20 \\
\hline \multicolumn{6}{|c|}{ Quality of institutions } \\
\hline Overall sample & 1.0 & 5.4 & -12.4 & 11.7 & 143 \\
\hline ECCU & 3.1 & 0.8 & 2.3 & 4.1 & 6 \\
\hline Small island states & 2.6 & 3.6 & -6.6 & 8.5 & 22 \\
\hline \multicolumn{6}{|c|}{ Quality of infrastructure } \\
\hline Overall sample & 9.5 & 14.9 & 0.1 & 100.0 & 138 \\
\hline ECCU & 24.2 & 14.5 & 8.1 & 43.4 & 6 \\
\hline Small island states & 20.7 & 24.6 & 0.6 & 100.0 & 19 \\
\hline
\end{tabular}

Source: Authors' calculations.

$1 / \mathrm{A}$ higher value indicates a more restrictive FDI policy.

2/ A higher value indicates a broader FDI incentives regime.

Consider first the bivariate relationship between FDI regimes and FDI performance. FDI restrictiveness is negatively and significantly correlated with FDI, but there is little evidence that FDI incentives are associated with higher FDI (Figures 5 and 6). These findings are consistent with past empirical studies of other regions, including surveys.

Higher statutory CIT rates and import-related tax rates are negatively related to FDI (Figures 7 and 8) because they lower the after-tax return to capital and raise production costs, thereby hindering investment. Subject to fiscal constraints, and given the above average statutory tax rates in the ECCU, there appears to be scope to reduce tax rates and broaden the tax base. 
Figure 5. FDI/GDP and FDI Restrictions Index 1/

(In percent)

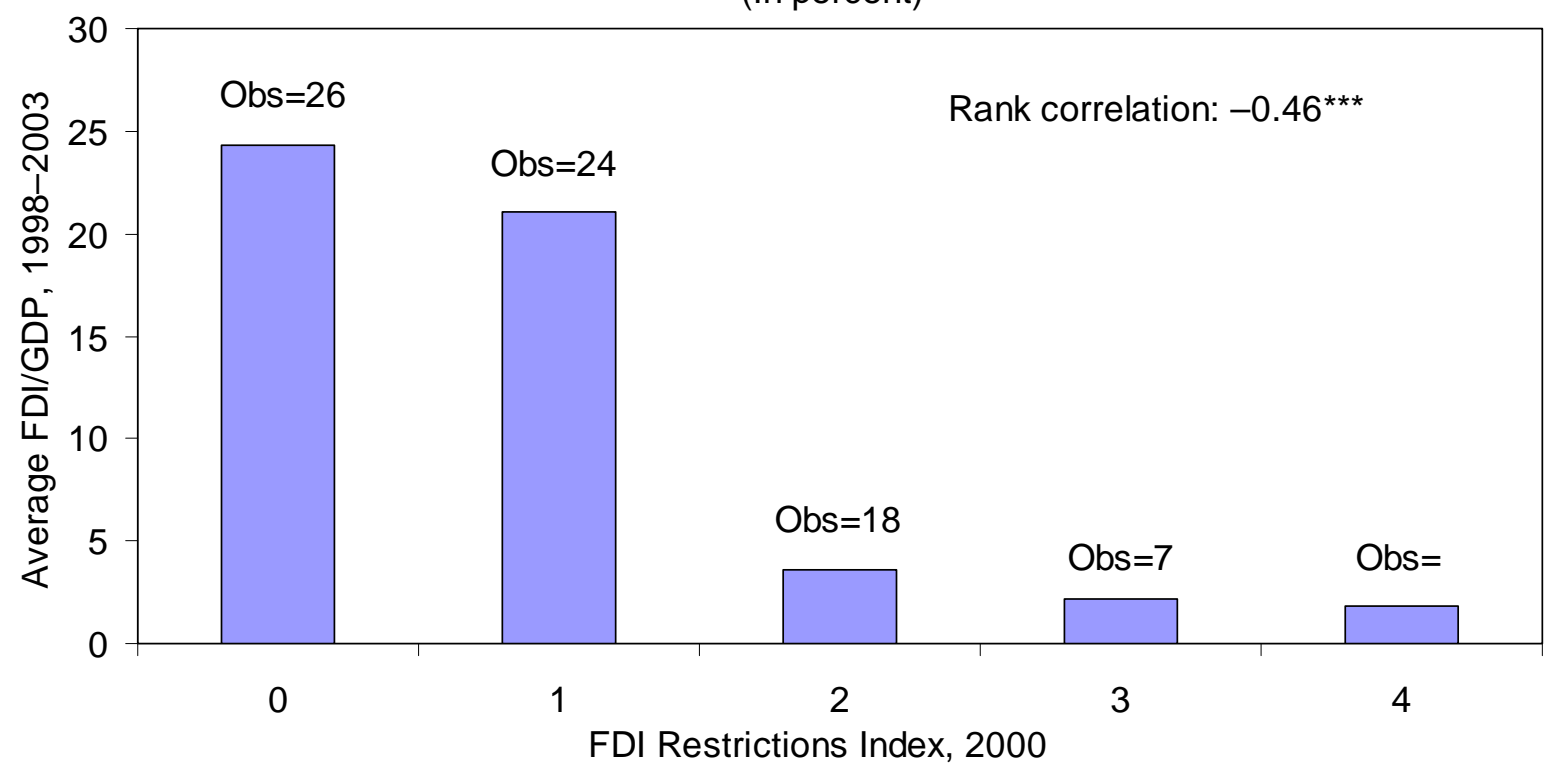

Sources: UNCTAD, World Investment Report (2004); Wei (2000); and authors' calculations. $1 /$ A higher value indicates a more restrictive FDI policy. Note: ** ${ }^{\star}$ significant at 1 percent.

Figure 6. FDI/GDP and FDI Incentives Index 1/

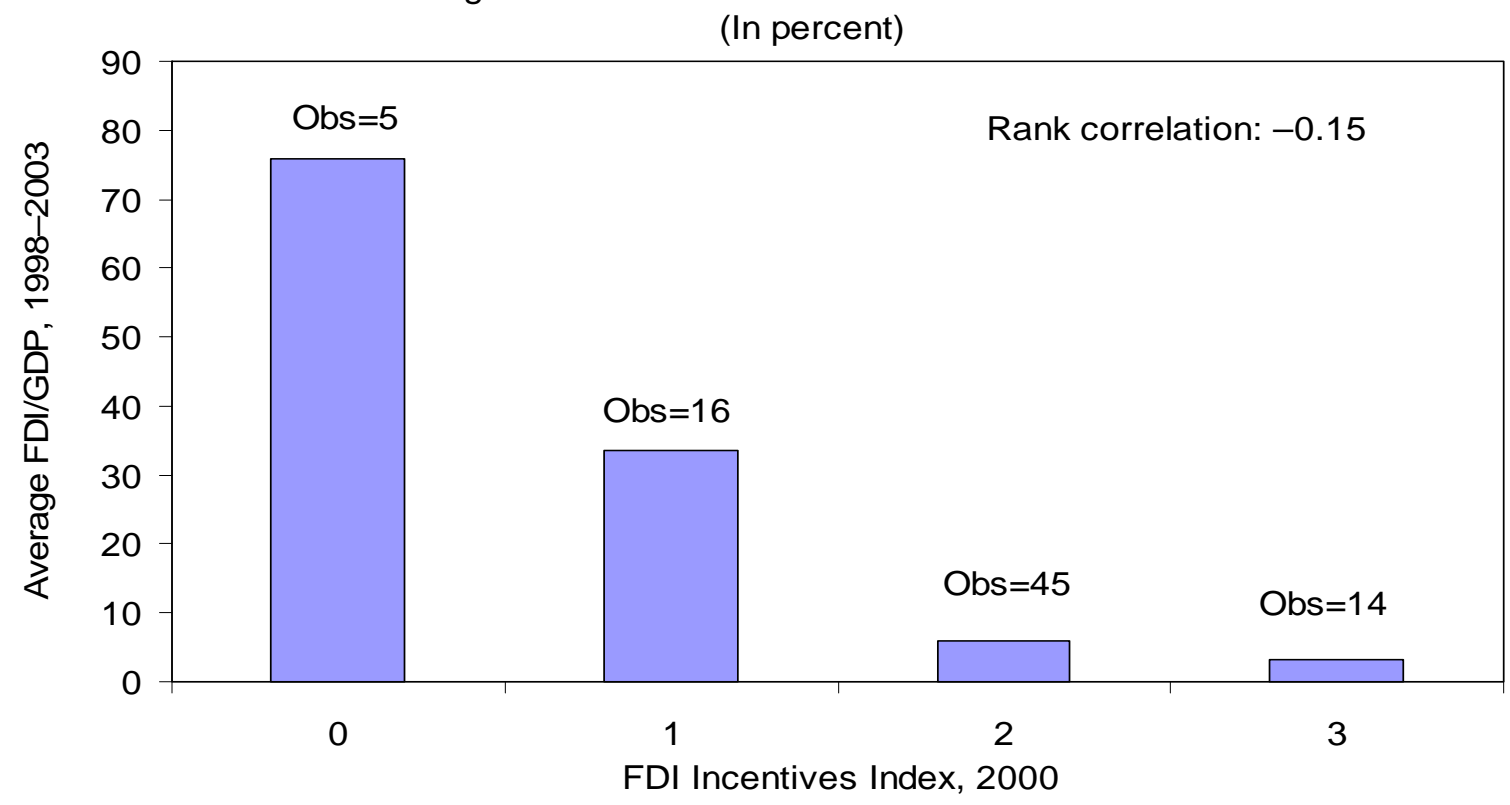

Sources: UNCTAD, World Investment Report (2004); Wei (2000); and authors' calculations. 1/ A higher value indicates a more restrictive FDI policy. 
Figure 7. FDI/GDP and Statutory Corporate Income Tax Rate (In percent)

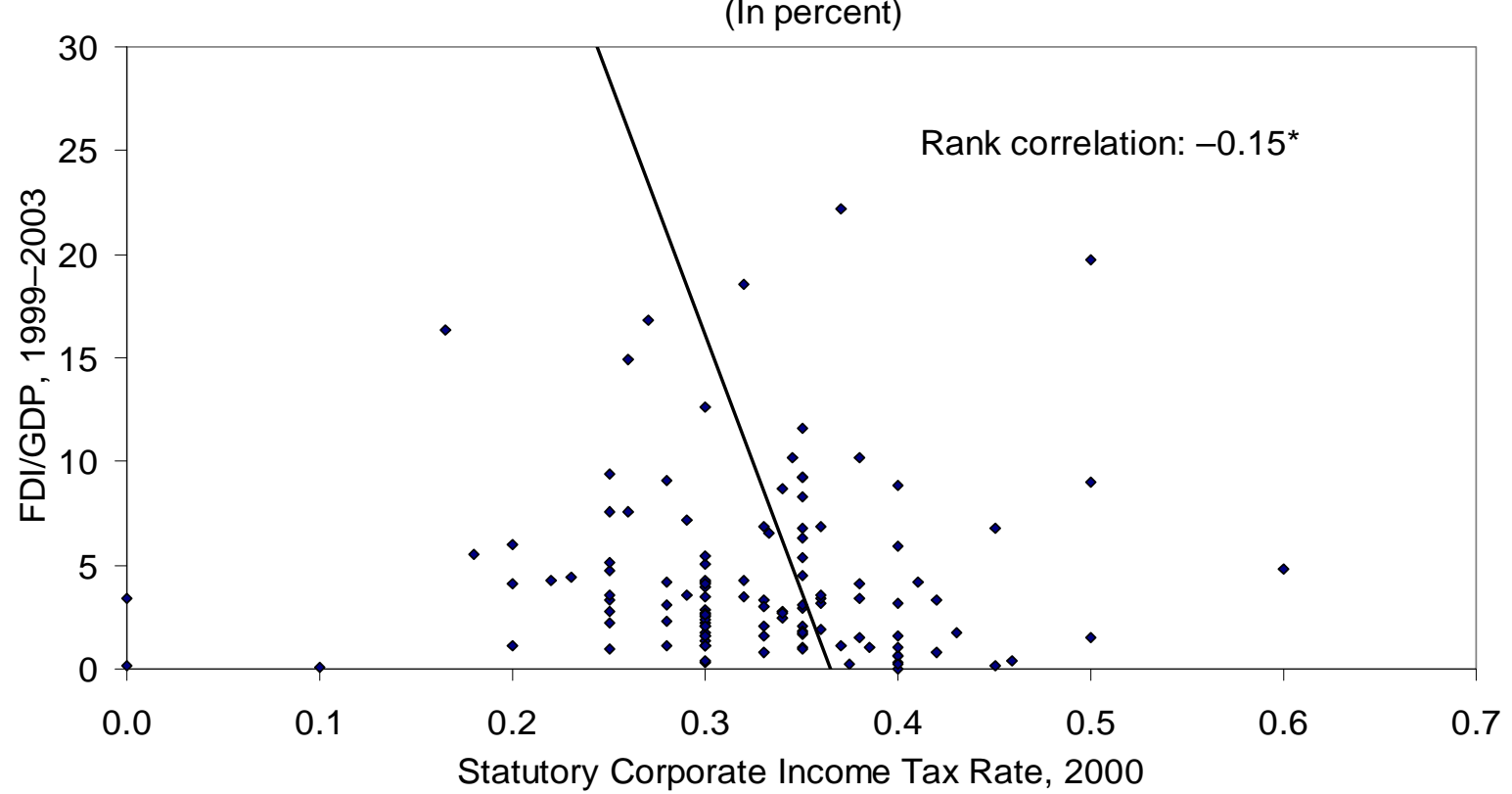

Sources: UNCTAD, World Investment Report (2004); Country authorities; and authors' calculations.

Note: * significant at 10 percent.

Figure 8. FDI/GDP and Statutory Import-Related Tax Rate (In percent)

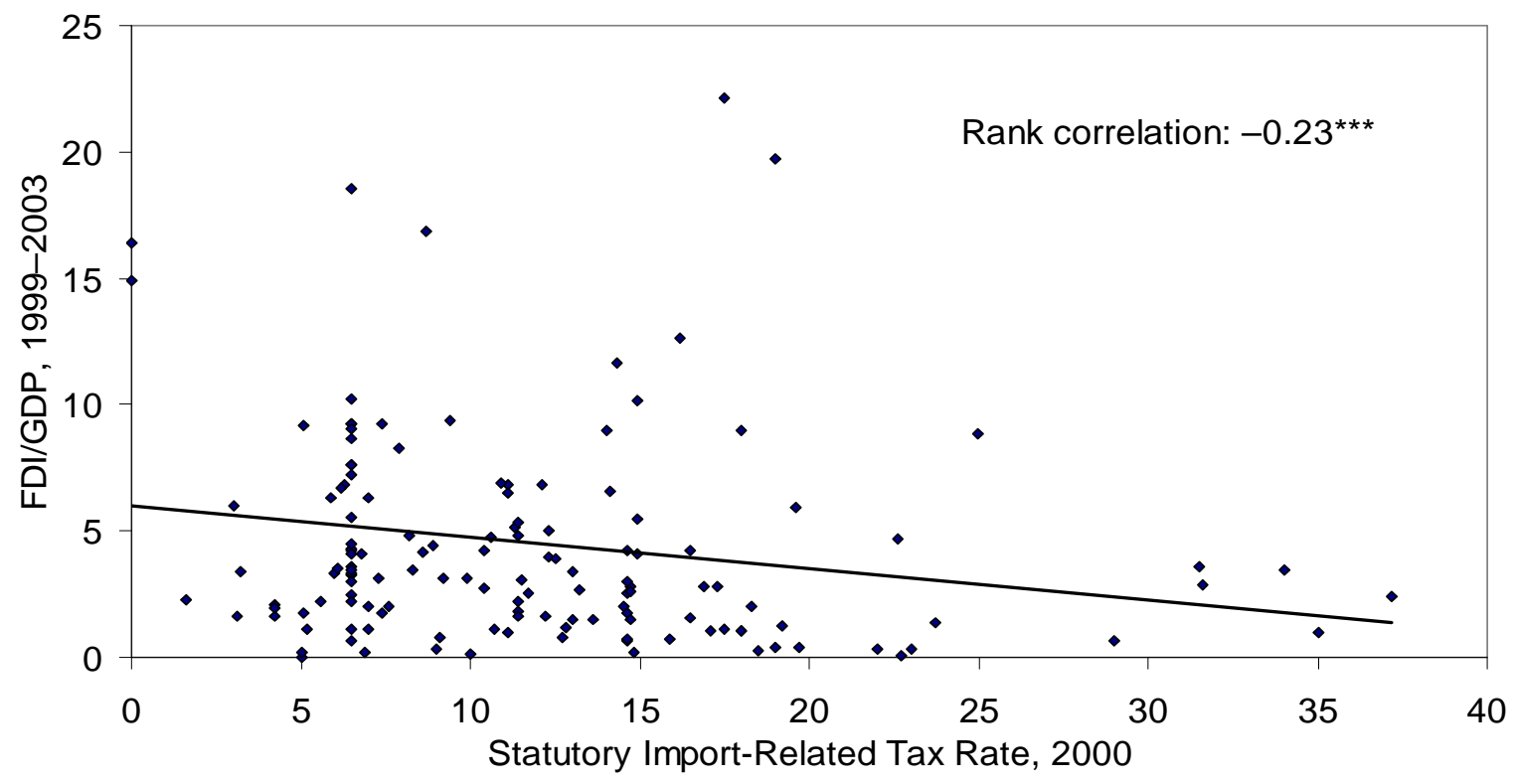

Sources: UNCTAD, World Investment Report (2004); Country authorities; and authors' calculations.

Note: ${ }^{\star \star \star}$ significant at 1 percent. 
Cross-country regression analyses confirm the absence of a relationship between incentives and FDI (Tables 8 and 9). The incentives index is insignificant in all econometric specifications, including different dependent variables for FDI (FDI/GDP and FDI per capita). The results also confirm the importance of lower statutory CIT rates, no FDI restrictions, and better institutional quality, and are in line with the emerging consensus in the literature. ${ }^{14}$

Table 8. Cross Country Ordinary Least Square Regressions 1/

Dependent Variable: Ln (FDI/GDP)

\begin{tabular}{|c|c|c|c|c|c|c|c|}
\hline & $(1)$ & $(2)$ & (3) & $(4)$ & $(5)$ & (6) & $(6)$ \\
\hline FDI restrictions & $\begin{array}{l}-0.220^{*} \\
(0.101)\end{array}$ & $\begin{array}{c}-0.246^{*} \\
(0.113)\end{array}$ & $\begin{array}{c}-0.309^{\star} \\
(0.118)\end{array}$ & $\begin{array}{l}-0.254^{\star} \\
(0.113)\end{array}$ & $\begin{array}{c}-0.220^{*} \\
(0.103)\end{array}$ & $\begin{array}{l}-0.165 \\
(0.102)\end{array}$ & $\begin{array}{l}-0.164 \\
(0.104)\end{array}$ \\
\hline FDI incentives & & & $\begin{array}{l}-0.255 \\
(0.178)\end{array}$ & $\begin{array}{c}-0.142 \\
(0.172)\end{array}$ & $\begin{array}{c}-0.006 \\
(0.156)\end{array}$ & $\begin{array}{c}0.077 \\
(0.154)\end{array}$ & $\begin{array}{c}0.081 \\
(0.159)\end{array}$ \\
\hline Average import tariff & $\begin{array}{c}0.000 \\
(0.017)\end{array}$ & & & & $\begin{array}{c}0.000 \\
(0.017)\end{array}$ & & $\begin{array}{c}-0.002 \\
(0.018)\end{array}$ \\
\hline Corporate income tax & & $\begin{array}{c}-0.047^{\star *} \\
(0.014)\end{array}$ & & $\begin{array}{c}-0.044^{* *} \\
(0.014)\end{array}$ & & $\begin{array}{c}-0.009 \\
(0.015)\end{array}$ & $\begin{array}{l}-0.009 \\
(0.015)\end{array}$ \\
\hline Quality of institutions & $\begin{array}{c}0.041 \\
(0.026)\end{array}$ & $\begin{array}{c}0.053 \\
(0.027)\end{array}$ & $\begin{array}{c}0.041 \\
(0.031)\end{array}$ & $\begin{array}{c}0.044 \\
(0.029)\end{array}$ & $\begin{array}{c}0.041 \\
(0.027)\end{array}$ & $\begin{array}{c}0.033 \\
(0.027)\end{array}$ & $\begin{array}{c}0.032 \\
(0.028)\end{array}$ \\
\hline Quality of infrastructure & & & & & & $\begin{array}{c}0.011 \\
(0.007)\end{array}$ & $\begin{array}{c}0.011 \\
(0.007)\end{array}$ \\
\hline ECCU fixed effect & $\begin{array}{c}0.806 \\
(0.437)\end{array}$ & $\begin{array}{c}0.867 \\
(0.496)\end{array}$ & $\begin{array}{c}0.613 \\
(0.518)\end{array}$ & $\begin{array}{c}0.861 \\
(0.497)\end{array}$ & $\begin{array}{c}0.806 \\
(0.440)\end{array}$ & $\begin{array}{c}0.817 \\
(0.423)\end{array}$ & $\begin{array}{c}0.828 \\
(0.444)\end{array}$ \\
\hline Observations & 77 & 80 & 80 & 80 & 77 & 75 & 75 \\
\hline R-squared & 0.19 & 0.29 & 0.20 & 0.30 & 0.19 & 0.24 & 0.24 \\
\hline Adjusted R-squared & 0.15 & 0.25 & 0.16 & 0.25 & 0.14 & 0.18 & 0.16 \\
\hline
\end{tabular}

1/ Standard errors in parentheses. * significant at 5 percent; ** significant at 1 percent.

\footnotetext{
${ }^{14}$ The statistical significance of the CIT rate is driven by three 'tax haven' countries. When these countries are excluded from the estimation, the CIT has the correct sign, but is statistically insignificant. Instead, the FDI restrictions index and the ECCU fixed effect become statistically more significant.
} 
Table 9. Cross Country Ordinary Least Square Regressions 1/

Dependent Variable: Ln (FDI per capita)

\begin{tabular}{|c|c|c|c|c|c|c|c|}
\hline & $(1)$ & $(2)$ & (3) & $(4)$ & $(5)$ & $(6)$ & (6) \\
\hline FDI restrictions & $\begin{array}{c}-0.193 \\
(0.125)\end{array}$ & $\begin{array}{c}-0.215 \\
(0.138)\end{array}$ & $\begin{array}{l}-0.293^{*} \\
(0.143)\end{array}$ & $\begin{array}{l}-0.229 \\
(0.138)\end{array}$ & $\begin{array}{c}-0.197 \\
(0.127)\end{array}$ & $\begin{array}{c}-0.122 \\
(0.120)\end{array}$ & $\begin{array}{l}-0.100 \\
(0.121)\end{array}$ \\
\hline FDI incentives & & & $\begin{array}{c}-0.392 \\
(0.215)\end{array}$ & $\begin{array}{c}-0.261 \\
(0.209)\end{array}$ & $\begin{array}{c}-0.067 \\
(0.193)\end{array}$ & $\begin{array}{c}0.020 \\
(0.181)\end{array}$ & $\begin{array}{c}0.072 \\
(0.185)\end{array}$ \\
\hline Average import tariff & $\begin{array}{c}-0.019 \\
(0.021)\end{array}$ & & & & $\begin{array}{c}-0.017 \\
(0.021)\end{array}$ & & $\begin{array}{l}-0.027 \\
(0.021)\end{array}$ \\
\hline Corporate income tax & & $\begin{array}{c}-0.056^{\star \star} \\
(0.017)\end{array}$ & & $\begin{array}{c}-0.051^{\star *} \\
(0.017)\end{array}$ & & $\begin{array}{c}-0.014 \\
(0.017)\end{array}$ & $\begin{array}{c}-0.016 \\
(0.017)\end{array}$ \\
\hline Quality of institutions & $\begin{array}{l}0.264^{\star *} \\
(0.032)\end{array}$ & $\begin{array}{l}0.290 * * \\
(0.033)\end{array}$ & $\begin{array}{l}0.271^{\star \star} \\
(0.037)\end{array}$ & $\begin{array}{l}0.275^{\star \star} \\
(0.035)\end{array}$ & $\begin{array}{l}0.261^{\star *} \\
(0.033)\end{array}$ & $\begin{array}{l}0.264^{\star \star} \\
(0.031)\end{array}$ & $\begin{array}{l}0.253^{\star \star} \\
(0.032)\end{array}$ \\
\hline Quality of infrastructure & & & & & & $\begin{array}{l}0.016^{*} \\
(0.008)\end{array}$ & $\begin{array}{c}0.015 \\
(0.008)\end{array}$ \\
\hline ECCU fixed effect & $\begin{array}{c}0.909 \\
(0.539)\end{array}$ & $\begin{array}{c}0.888 \\
(0.606)\end{array}$ & $\begin{array}{c}0.589 \\
(0.626)\end{array}$ & $\begin{array}{c}0.877 \\
(0.604)\end{array}$ & $\begin{array}{c}0.899 \\
(0.543)\end{array}$ & $\begin{array}{c}0.846 \\
(0.499)\end{array}$ & $\begin{array}{l}1.035^{\star} \\
(0.518)\end{array}$ \\
\hline Observations & 77 & 80 & 80 & 80 & 77 & 75 & 75 \\
\hline R-squared & 0.60 & 0.59 & 0.56 & 0.60 & 0.60 & 0.66 & 0.67 \\
\hline Adjusted R-squared & 0.58 & 0.57 & 0.53 & 0.58 & 0.58 & 0.63 & 0.63 \\
\hline
\end{tabular}

1/ Standard errors in parentheses; * significant at 5 percent; **significant at 1 percent.

\section{Policy Alternatives}

A development strategy based on increasing the amount of concessions to investors is unlikely to result in increased investment and growth. A re-evaluation of the strategy of using incentives to promote development is needed, possibly within a regional context. A regional approach to harmonizing concessions would help limit each country's revenue losses, and avoid the tax competition that has produced a race to the bottom.

A strategy focused on enhancing the investment climate is likely to be more effective in raising investment and growth rates. Some countries, such as Mexico and Hong Kong SAR, have attracted substantial investments without tax incentives. Mexico's tourism industry attracted more than US $\$ 2 \frac{1}{4}$ billion in new investments in 2003 without income tax holidays. In 2004, Mexico received a historic high of over 20 million international visitors and over US $\$ 10$ billion in tourism receipts. Hong Kong SAR has been a top performer in attracting 
FDI, with a uniform 15 percent income tax rate and no tax incentives. Enhancing the investment climate entails addressing key investor concerns such as improving the regulatory environment, developing infrastructure, lowering statutory tax rates (to the extent permitted by the macroeconomic situation), and raising labor productivity through skills acquisition and labor market reform.

The preceding analysis highlights the importance of reducing concessions significantly or phasing them out and broadening the tax base, while lowering statutory tax rates. If tax rates were lowered but concessions not phased out, the fiscal and macroeconomic environment could deteriorate, which would deter investment and lower growth. Moreover, there is an urgent need to strengthen data gathering on the costs and benefits of the tax concessions through routine monitoring and review, and to make available public information on the costs and benefits of each of the concessions granted. In this regard, the cost of all concessions granted could be published regularly in a tax expenditure annex to the budget.

Meanwhile, concessions should be nondiscretionary, transparent, and limited in size, duration and scope. Revising legislation on concession-related investment to make them rule based with clear specification of eligibility criteria would improve the investment climate, help level the playing field among investors, and alleviate the administrative burden on the cabinet and line ministries. Eliminating ad hoc concessions for social and welfare purposes should be a priority and all social spending should be incorporated in the budget process. ${ }^{15}$ Respecting fiscal constraints is also critical; borrowing to provide concessions would deteriorate the macroeconomic environment.

When incentives are granted, careful consideration needs to be given to the choice of instrument. Incentives may be granted in a variety of forms, each with differing characteristics. ${ }^{16}$ CIT holidays are relatively easy to administer, but have several disadvantages. Since profits are exempted irrespective of amount, they tend to benefit investors with high profits who would likely have undertaken the investment even without the incentive. Moreover, they increase the potential of tax avoidance through transfer pricing. Some investors may not feel the need to maintain records, which hinders oversight. Indirect tax incentives such as exemptions from import-related taxes are also prone to abuse, including by the diversion of qualified purchases to those not intended to receive the incentives. They should be avoided.

Tax credits for investment could be considered in place of holidays. Credits have been used recently in Grenada, and have advantages over holidays. They target investment directly and

\footnotetext{
${ }^{15}$ In Dominica, the policy since mid-December 2003 has been to not grant ad hoc import concessions.

${ }^{16}$ This section draws on Zee, Stotsky, and Ley (2002).
} 
enhance transparency by requiring investors to file tax returns. However, credits may reduce investors' tax liability to zero in some periods, raising the question of whether the administrative costs of a tax credit system should be borne when there are no tax revenues. The substantial revenue forgone suggests the importance of monitoring to keep track of the revenue costs of incentives and lower the potential for abuse.

Tax credits have two disadvantages. Investments may be distorted towards short-lived assets since investors get tax credits each time an asset is replaced. Investors may also be enticed to claim multiple credits by buying and selling the same asset or by buying assets for other firms or persons not entitled to receive credits. Monitoring systems may thus be needed to prevent abuse, including, for instance, by specifying minimum holding periods for assets.

Accelerated depreciation and loss-carrying-forward provisions could provide a superior alternative. They have the advantages of tax credits - targeting investment directly and enhancing transparency - while not distorting investments towards short-lived assets nor making it beneficial for firms to abuse the system. An implication of changing the time profile of depreciation allowances, however, is that they do not provide additional allowances such as those given in a tax credit system. Hence, they may provide smaller benefits to investors.

One might argue that tax holidays provide greater returns for investors than accelerated depreciation and, therefore, lead to more investments. This is not necessarily the case. The following example illustrates how accelerated depreciation and loss-carry-forward provisions might work in practice and how they might compare with CIT holidays in affecting the return on investments. Consider an investment that, for simplicity, depreciates equally and completely over three periods. There are no profits in the first period, but there are profits in subsequent periods. A tax holiday for all three periods would yield greater returns for an investor than a holiday for one or two periods. For an investment of $\$ 30$, tax rate of 30 percent and discount rate of 10 percent, Table 10 illustrates the net profit for an investor under a one-period, two-period, and three-period holiday. In the example and without loss of generality, the profit level is chosen to set the present value of the three-period holiday at zero.

Table 10. Tax Holidays: An Illustrative Example

\begin{tabular}{|c|c|c|c|c|c|c|c|}
\hline \multirow[b]{2}{*}{ Time } & \multirow[b]{2}{*}{ Investment } & \multirow[b]{2}{*}{$\begin{array}{l}\text { Profit Before } \\
\text { Depreciation }\end{array}$} & \multirow[b]{2}{*}{$\begin{array}{c}\text { Standard } \\
\text { Depreciation }\end{array}$} & \multirow[b]{2}{*}{$\begin{array}{c}\text { Pre-tax } \\
\text { Profit After } \\
\text { Depreciation }\end{array}$} & \multicolumn{3}{|c|}{ Net (After-tax) Profit } \\
\hline & & & & & $\begin{array}{l}\text { 1-Period } \\
\text { Holiday }\end{array}$ & $\begin{array}{c}\text { 2-Period } \\
\text { Holiday }\end{array}$ & $\begin{array}{c}\text { 3-Period } \\
\text { Holiday }\end{array}$ \\
\hline 1 & 30.0 & 0.0 & 10.0 & -10.0 & -10.0 & -10.0 & -10.0 \\
\hline 2 & 0.0 & 15.8 & 10.0 & 5.8 & 4.0 & 5.8 & 5.8 \\
\hline 3 & 0.0 & 15.8 & 10.0 & 5.8 & 4.0 & 4.0 & 5.8 \\
\hline \multicolumn{2}{|c|}{ Present value of profits } & & & & -2.7 & 1.3 & 0.0 \\
\hline
\end{tabular}

Note: A tax rate of 30 percent and a discount rate of 10 percent are assumed. 
Now consider accelerated depreciation and loss carry forward. The investor can depreciate a greater amount in the initial period and smaller amounts in subsequent periods, compared with standard depreciation. The nominal value of depreciation allowances is similar under both accelerated depreciation and standard depreciation, but the time profile for depreciation is swifter for the former. Losses in the initial period are larger, and losses may be carried over to later periods.

In Table 11, the loss in the initial period (\$8.8) exceeds the pre-tax profits in the second period (\$7). Hence, the tax liability is zero in the second period. The residual amount of loss (\$1.8) is carried over to the third period and deducted from pre-tax profits.

Table 11. Accelerated Depreciation and Loss Carry Forward: An Illustrative Example

\begin{tabular}{|c|c|c|c|c|c|c|}
\hline Time & Investment & $\begin{array}{l}\text { Profit Before } \\
\text { Depreciation }\end{array}$ & $\begin{array}{c}\text { Accelerated } \\
\text { Depreciation }\end{array}$ & $\begin{array}{c}\text { Pre-tax Profit } \\
\text { After } \\
\text { Depreciation }\end{array}$ & Tax & $\begin{array}{c}\text { After-tax } \\
\text { Profit }\end{array}$ \\
\hline 1 & 30.0 & 0.0 & 12.5 & -12.5 & -3.8 & -8.8 \\
\hline 2 & 0.0 & 15.8 & 8.8 & 7.0 & 0.0 & 7.0 \\
\hline 3 & 0.0 & 15.8 & 8.8 & 7.0 & 1.6 & 5.4 \\
\hline \multicolumn{6}{|c|}{ Present value of profits } & 1.9 \\
\hline
\end{tabular}

Note: A tax rate of 30 percent and a discount rate of 10 percent are assumed.

It is more profitable to invest under an accelerated depreciation scheme than under tax holidays in this example. The accelerated time profile of depreciation and ability to carry forward losses changes the accounting profile of losses and profits, yielding a higher present value of net profits under accelerated depreciation than under a full tax holiday.

The result holds under a variety of alternative assumptions. For instance, even greater accelerated depreciation would result in a larger present value of net profits, as long as the investor is able to carry forward losses. Similarly, the result would hold if the number of periods are increased or the level of profits in subsequent periods are changed.

If the investor does not experience losses in the initial period or if the investor is unable to carry forward losses, then the tax holiday yields greater profits than does accelerated depreciation. For projects that yield profits in the initial set up period, it is unclear whether incentives are needed to generate the investments. In the ECCU, hotel and tourism projects would not be expected to generate profits during the initial construction and set up period. For these cases, accelerated depreciation with a reasonable length of time over which losses can be carried forward would be preferable to holidays, even on the basis of project profitability. 


\section{ConClusions}

Tax concessions have been employed as a key component of the investment and development strategy of ECCU member countries. Considerable discretion has been applied in the granting of concessions-mainly import-related tax concessions and corporate income tax holidays - for investment and social purposes. Incentives have been given not only for new investments but also for ones that have been in operation for several years. Larger firms have tended to receive more incentives and for longer periods of time.

The benefits in terms of FDI appear to be limited, but the costs in terms of forgone revenue are substantial. A broad cross-country analysis shows that FDI is not related to incentives. Rather, in line with results from investor surveys and regression analyses in the economics literature, lower statutory tax rates, the absence of FDI restrictions, and better institutional and infrastructural quality are key to raising FDI. Estimates of forgone revenue from tax concessions range from $91 / 2$ to 16 percent of GDP annually for the ECCU countries. Therefore, the strategy of using incentives to promote development needs to be re-evaluated urgently, possibly within a regional context.

The development strategy should focus on enhancing the investment climate, including by improving the regulatory environment, developing infrastructure, and raising labor productivity through skills acquisition and labor market reform. Statutory tax rates should be lowered and the tax base broadened. Concessions should be reduced significantly or phased out. Existing concessions should be monitored and reviewed routinely, and the costs and benefits publicized of each concession granted.

When tax incentives are granted for investment purposes, they should be nondiscretionary, transparent, and limited in size, duration and scope. Accelerated depreciation and losscarrying-forward provisions should be considered in place of tax holidays, which are inefficient and prone to abuse. Indirect tax incentives are also prone to abuse and should be avoided. 


\section{Appendix I. Calculating the Change in Revenue from Removing Import-Related Tax Concessions}

The current revenue intake from imports given existing tax concessions can be expressed as: $v_{c} * \bar{P}_{c i f} * t_{e}$, where $v_{c}$ is the quantity of imports with the tax concessions, $\bar{P}_{c i}$ is the average c.i.f value of the imports and is normalized to take the value of 1 , and $t_{e}$ is the average effective tax rate. The average effective after-tax import price is: $P_{a f t}=1+t_{e}$.

The removal of tax concessions raises the average after-tax import price: $\Delta P_{a f t} / P_{a f t}=\left(t-t_{e}\right) /\left(1+t_{e}\right)$, where $t$ is the average statutory tax rate for imports and $t \geq t_{e}$. The change in the average after-tax import price affects the quantity of imports: this relationship is measured by the import price elasticities: $\frac{\Delta v / v}{\Delta P_{\text {aft }} / P_{\text {aft }}}=\varepsilon$, where $\varepsilon \leq 0$ generally. It follows that a change in quantity of imports is: $\Delta v=v-v_{c}=v_{c} \varepsilon\left(t-t_{e}\right) /\left(1+t_{e}\right)$.

The change in revenue from imports after the removal of tax concessions will then be:

$$
\Delta R=v t-v_{c} t_{e}=v_{c}\left\{1+\varepsilon\left(t-t_{e}\right) /\left(1+t_{e}\right)\right\} t-v_{c} t_{e} .
$$

Adding and subtracting the term of $v_{c}\left\{1+\varepsilon\left(t-t_{e}\right) /\left(1+t_{e}\right)\right\} t_{e}$ and rearranging the terms arrives at the following expression:

$$
\Delta R=v_{c}\left\{1+\varepsilon\left(t-t_{e}\right) /\left(1+t_{e}\right)\right\}\left(t-t_{e}\right)+v_{c} t_{e}\left\{\varepsilon\left(t-t_{e}\right) /\left(1+t_{e}\right)\right\}
$$

The first term captures the after-tax price effect of removing tax concessions, while the second term captures the volume effect of a higher after-tax import price.

From this expression, it is straightforward to show that:

$$
\begin{aligned}
& \Delta R>0, \text { if } \varepsilon>-\left(1+t_{e}\right) / t ; \\
& \Delta R<0, \text { if } \varepsilon<-\left(1+t_{e}\right) / t ; \\
& \Delta R=0, \text { if } t=t_{e} ; \text { or } \varepsilon=-\left(1+t_{e}\right) / t ; \\
& \frac{\delta \Delta R}{\delta \varepsilon}=v_{c}\left\{\left(t-t_{e}\right) /\left(1+t_{e}\right)\right\} t>0
\end{aligned}
$$

Khan (1974) and Khan and Knight (1988) estimated that aggregate import price elasticities range from -0.4 to 1 for developing countries, with small open countries being more price inelastic with respect to imports. Given the average statutory and effective tax rates in the ECCU (about 41 and 26 percent, respectively), revenue will increase after removing tax concessions, and the increase is greater the more price inelastic the ECCU countries are to imports. 


\section{Appendix II. Constructing Foreign Direct Investment Regime Indices}

The FDI restrictions and incentives indices measure the government's policies towards FDI and are constructed using the methodology of Wei (2000). Each index is a sum of four variables, each of which takes a value of either 0 or 1 . Publicly available sources, including Pricewaterhouse Cooper's Investment Guides and various investment agency reports, were used to compile the indices. Table 1 below lists the data for 80 economies, including for the 40 mostly middle- and high-income countries in Wei (2000).

The FDI restrictions index measures whether: (1) there are controls on foreign exchange that interfere with the ability of foreign firms to import intermediate inputs or repatriate profits; (2) there is a ban on foreign investments in strategic sectors (in particular, national defense and the mass media); (3) there is a ban on foreign investments in other sectors where their presence would be considered harmless in most developed countries; and (4) there are limits on ownership share.

The FDI incentives index measures whether: (1) there are special incentives to invest in certain industries or geographical areas; (2) exports are specially promoted, including through export-processing zones and special economic zones; (3) there are tax concessions specific to foreign firms, excluding those designed specifically for export promotion; and (4) there are cash grants, subsidized loans, reduced rent for land use, or other nontax concessions specific to foreign firms. 
Appendix II. Table 1. Government Policies Toward Foreign Direct Investment, 2000

\begin{tabular}{|c|c|c|c|c|c|c|c|c|c|c|}
\hline \multirow[b]{2}{*}{ Country } & \multicolumn{5}{|c|}{ FDI Restrictions } & \multicolumn{5}{|c|}{ FDI Incentives } \\
\hline & $\begin{array}{c}\text { Foreign } \\
\text { Exchange } \\
\text { Controls } \\
\end{array}$ & $\begin{array}{c}\text { Exclusion } \\
\text { from Strategic } \\
\text { Sectors } \\
\end{array}$ & $\begin{array}{c}\text { Exclusion } \\
\text { from Other } \\
\text { Sectors }\end{array}$ & $\begin{array}{l}\text { Restrictions } \\
\text { on Owner- } \\
\text { ship Share }\end{array}$ & $\begin{array}{c}\text { Overall } \\
\text { Variable }\end{array}$ & $\begin{array}{l}\text { Industry \& } \\
\text { Geographic } \\
\text { Incentives }\end{array}$ & $\begin{array}{c}\text { Tax } \\
\text { Concessions } \\
\end{array}$ & $\begin{array}{c}\text { Nontax } \\
\text { Concessions } \\
\end{array}$ & $\begin{array}{c}\text { Export } \\
\text { Incentives }\end{array}$ & $\begin{array}{c}\text { Overall } \\
\text { Variable }\end{array}$ \\
\hline Argentina & 0 & 0 & 0 & 0 & 0 & 1 & 0 & 0 & 1 & 2 \\
\hline Australia & 0 & 1 & 0 & 0 & 1 & 1 & 0 & 0 & 1 & 2 \\
\hline Austria & 0 & 1 & 1 & 0 & 2 & 1 & 0 & 0 & 0 & 1 \\
\hline Barbados & 1 & 0 & 0 & 0 & 1 & 1 & 0 & 1 & 1 & 3 \\
\hline Belgium and Luxembourg & 0 & 1 & 0 & 0 & 1 & 1 & 0 & 0 & 1 & 2 \\
\hline Belize & 0 & 0 & 0 & 0 & 0 & 1 & 0 & 1 & 1 & 2 \\
\hline Bermuda & 0 & 0 & 1 & 0 & 1 & 0 & 0 & 0 & 0 & 0 \\
\hline Bolivia & 0 & 0 & 0 & 0 & 0 & 1 & 0 & 0 & 1 & 2 \\
\hline Botswana & 0 & 0 & 0 & 0 & 0 & 1 & 0 & 0 & 1 & 2 \\
\hline Cayman islands & 0 & 0 & 0 & 0 & 0 & 1 & 0 & 0 & 0 & 1 \\
\hline Chile & 1 & 1 & 0 & 0 & 2 & 1 & 0 & 0 & 1 & 2 \\
\hline China & 1 & 1 & 1 & 1 & 4 & 1 & 1 & 0 & 1 & 3 \\
\hline Colombia & 1 & 1 & 0 & 0 & 2 & 1 & 0 & 0 & 1 & 2 \\
\hline Costa Rica & 0 & 1 & 0 & 1 & 2 & 0 & 0 & 0 & 1 & 1 \\
\hline Cyprus & 0 & 0 & 0 & 1 & 1 & 1 & 0 & 1 & 1 & 3 \\
\hline Czech Republic & 0 & 1 & 0 & 0 & 1 & 0 & 1 & 1 & 0 & 2 \\
\hline Dominica & 0 & 0 & 0 & 0 & 0 & 1 & 0 & 0 & 1 & 2 \\
\hline Dominican Republic & 0 & 0 & 0 & 0 & 0 & 1 & 0 & 0 & 1 & 2 \\
\hline Ecuador & 0 & 0 & 0 & 1 & 1 & 1 & 0 & 0 & 1 & 2 \\
\hline Egypt & 0 & 1 & 1 & 1 & 3 & 0 & 1 & 1 & 1 & 3 \\
\hline Estonia & 0 & 0 & 0 & 0 & 0 & 0 & 0 & 0 & 0 & 0 \\
\hline
\end{tabular}


Appendix II. Table 1. Government Policies Toward Foreign Direct Investment, 2000

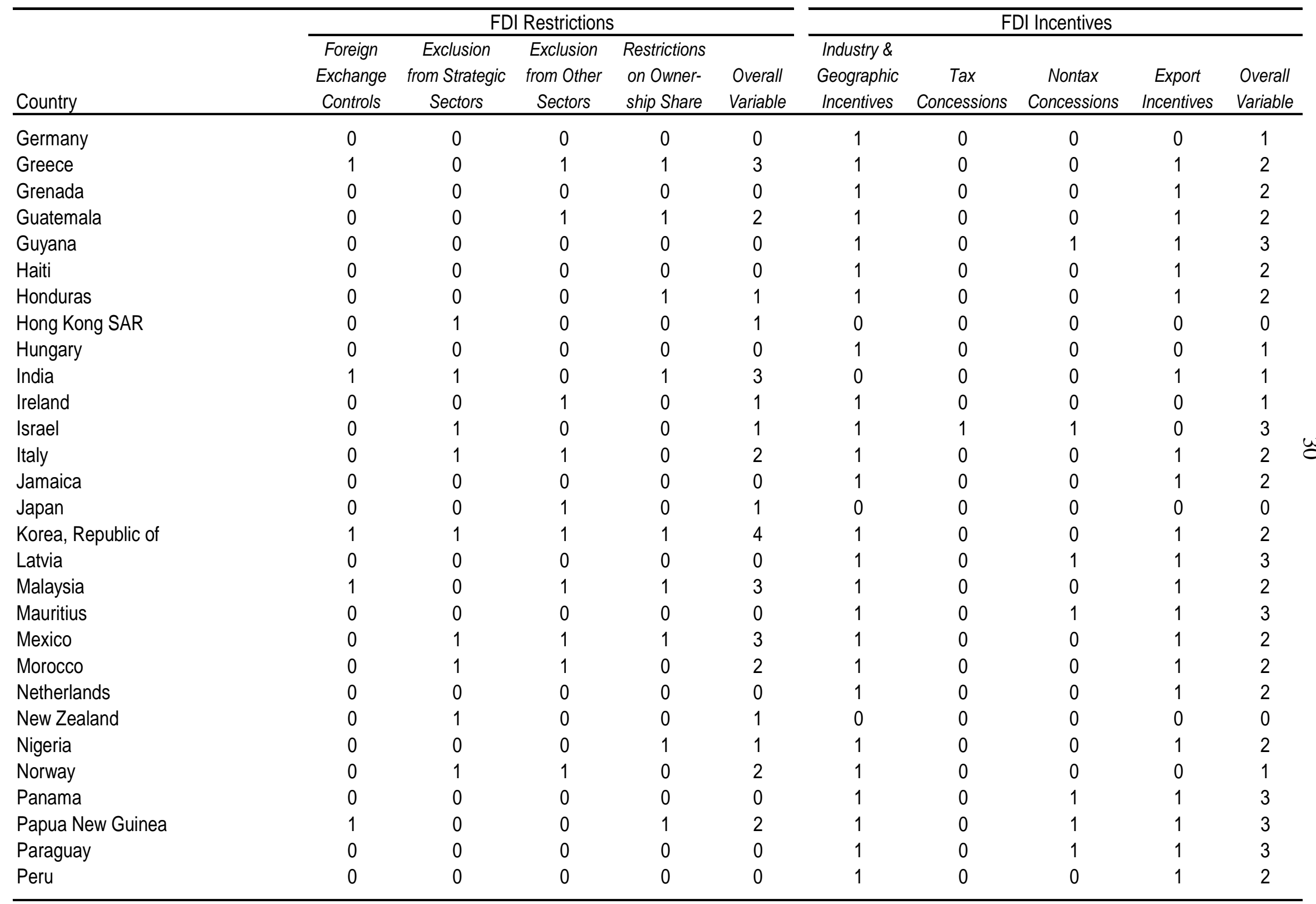


Appendix II. Table 1. Government Policies Toward Foreign Direct Investment, 2000

\begin{tabular}{|c|c|c|c|c|c|c|c|c|c|c|}
\hline \multirow[b]{2}{*}{ Country } & \multicolumn{5}{|c|}{ FDI Restrictions } & \multicolumn{5}{|c|}{ FDI Incentives } \\
\hline & $\begin{array}{c}\text { Foreign } \\
\text { Exchange } \\
\text { Controls } \\
\end{array}$ & $\begin{array}{c}\text { Exclusion } \\
\text { from Strategic } \\
\text { Sectors } \\
\end{array}$ & $\begin{array}{c}\text { Exclusion } \\
\text { from Other } \\
\text { Sectors }\end{array}$ & $\begin{array}{c}\text { Restrictions } \\
\text { on Owner- } \\
\text { ship Share }\end{array}$ & $\begin{array}{c}\text { Overall } \\
\text { Variable }\end{array}$ & $\begin{array}{l}\text { Industry \& } \\
\text { Geographic } \\
\text { Incentives }\end{array}$ & $\begin{array}{c}\text { Tax } \\
\text { Concessions } \\
\end{array}$ & $\begin{array}{c}\text { Nontax } \\
\text { Concessions } \\
\end{array}$ & $\begin{array}{c}\text { Export } \\
\text { Incentives }\end{array}$ & $\begin{array}{c}\text { Overall } \\
\text { Variable }\end{array}$ \\
\hline Philippines & 0 & 0 & 0 & 0 & 1 & 1 & 0 & 0 & 1 & 2 \\
\hline Poland & 1 & 0 & 0 & 0 & 1 & 1 & 0 & 0 & 1 & 2 \\
\hline Portugal & 0 & 1 & 0 & 0 & 1 & 1 & 0 & 0 & 1 & 2 \\
\hline Saint Kitts and Nevis & 0 & 0 & 0 & 0 & 0 & 1 & 0 & 0 & 1 & 2 \\
\hline Saint Lucia & 0 & 0 & 0 & 0 & 0 & 1 & 0 & 0 & 1 & 2 \\
\hline Saint Vincent and the Grenadines & 0 & 0 & 0 & 0 & 0 & 1 & 0 & 0 & 1 & 2 \\
\hline Samoa & 0 & 0 & 0 & 1 & 1 & 1 & 0 & 1 & 1 & 3 \\
\hline Seychelles & 1 & 0 & 0 & 0 & 1 & 1 & 0 & 0 & 1 & 2 \\
\hline Singapore & 0 & 1 & 0 & 0 & 1 & 1 & 0 & 0 & 1 & 2 \\
\hline Taiwan & 1 & 1 & 1 & 1 & 4 & 1 & 0 & 0 & 1 & 2 \\
\hline Thailand & 0 & 0 & 0 & 1 & 1 & 1 & 0 & 0 & 1 & 2 \\
\hline Trinidad and Tobago & 0 & 0 & 0 & 0 & 0 & 1 & 0 & 0 & 1 & 2 \\
\hline Tunisia & 0 & 1 & 1 & 1 & 3 & 1 & 0 & 1 & 1 & 3 \\
\hline Turkey & 1 & 1 & 0 & 0 & 2 & 1 & 0 & 0 & 1 & 2 \\
\hline Ukraine & 1 & 1 & 1 & 1 & 4 & 1 & 0 & 0 & 0 & 1 \\
\hline United Arab Emirates & 0 & 0 & 0 & 1 & 1 & 0 & 0 & 0 & 1 & 1 \\
\hline United Kingdom & 0 & 0 & 0 & 0 & 0 & 1 & 0 & 0 & 1 & 2 \\
\hline United States & 0 & 1 & 0 & 0 & 1 & 0 & 1 & 0 & 1 & 2 \\
\hline Uruguay & 0 & 1 & 0 & 0 & 1 & 1 & 0 & 0 & 1 & 2 \\
\hline Venezuela, R.B. & 0 & 1 & 0 & 0 & 1 & 1 & 0 & 0 & 1 & 2 \\
\hline
\end{tabular}




\section{REFERENCES}

Andrews, L., and K. Williams, 1999, "Improving the Administration for Granting Tax Concessions in the OECS,” (unpublished; Basseterre, St. Kitts: Eastern Caribbean Central Bank).

Bain, L., 1995, “Tax Concessions and their Impact on the Revenue Base of the ECCB Territories,” (unpublished; Basseterre, St. Kitts: Eastern Caribbean Central Bank).

Bauer, A., P. Cashin and S. Panth, 2008, The Caribbean: Enhancing Economic Integration (Washington D.C.: International Monetary Fund).

Chai, J., and R. Goyal, 2006, “Tax Concessions and Foreign Direct Investment in the Eastern Caribbean Currency Union,” in R. Sahay, D.O. Robinson and P. Cashin (eds), The Caribbean: From Vulnerability to Sustained Growth (Washington D.C.: International Monetary Fund), pp. 258-84.

Easson, A., 2004, Tax Incentives for Foreign Direct Investment (New York: Kluwer Law International).

Foreign Investment Advisory Service (FIAS), 2004, Caribbean Foreign Investor Perceptions Survey (Washington D.C.: World Bank).

Khan, M., 1974, “The Structure and Behavior of Imports of Venezuela,” The Review of Economics and Statistics, Vol. 57, pp. 221-24.

Khan, M., and M. Knight, 1988, "Important Compression and Export Performance in Developing Countries,” The Review of Economics and Statistics, Vol. 70, pp. 315-21.

Lecraw, D., 2003, Investment Incentives and Harmonization. Prepared for Inter-American Development Bank/Multilateral Investment Fund Project on Investment Frameworks in CARICOM, (unpublished; Washington).

Sosa, S., 2006, “Tax Incentives and Investment in the Eastern Caribbean,” IMF Working Paper 06/23 (Washington D.C.: International Monetary Fund).

UN Conference on Trade and Development (UNCTAD), 1996, Incentives and Foreign Direct Investment (New York: UNCTAD Division on Transnational Corporations and Investment). , 2004, World Investment Report (New York: UN Conference on Trade and Development). 
Wei, S. J., 2000, “Local Corruption and Global Capital Flows,” Brookings Papers on Economic Activities No. 2, pp. 303-54.

World Bank, 2005, Towards a New Agenda for Growth: Organization of Eastern Caribbean States (Washington D.C.: World Bank).

Zee, H., J. Stotsky, and E. Ley, 2002, “Tax Incentives for Business Investment: A Primer for Policy Makers in Developing Countries,” World Development, 30, pp. 1497-516. 